DOI: $10.24850 /$ j-tyca-2021-02-02

Articles

\title{
Socio-spatial analysis of residential water demand in Mexico City
}

\section{Análisis socio-espacial de la demanda doméstica de agua en la Ciudad de México}

Arturo Ramos-Bueno1, ORCID: https://orcid.org/0000-0002-4882-1348

María Perevochtchikova2, ORCID: https://orcid.org/0000-0001-93498570

Heejun Chang ${ }^{3}$, ORCID: https://orcid.org/0000-0002-5605-6500

1Posgrado en Geografía, Universidad Nacional Autónoma de México, Mexico City, Mexico, arambue@gmail.com

${ }^{2}$ Centro de Estudios Demográficos, Urbanos y Ambientales, El Colegio de México, A.C., Mexico City, Mexico, mperevochtchikova@colmex.mx

${ }^{3}$ Deparment of Geography, Portland State University, Portland, Oregon, USA, changh@pdx.edu

Corresponding author: Arturo Ramos Bueno, arambue@gmail.com 


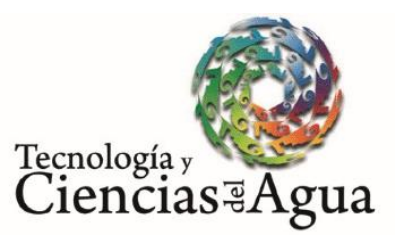

\section{Abstract}

Water management in cities has turned increasingly challenging, as urban water demand escalation takes place in a context of reduction of available freshwater sources. These concerns have evidenced the need to integrate water supply, drainage, and sanitation from the Integrated Urban Water Management (IUWM) paradigm. To study water supply component, it is important to consider the analysis of urban water demand determinants. In the case of Mexico City there is a lack of an accurate diagnosis for these determinants despite the fact it faces multiple water problems. Therefore, the present study aims to estimate residential water demand and its determinants in Mexico City at a neighborhood scale for the year 2010, based on official measured data. Analyzed determinants are related to socioeconomic, urban density and access to water services issues; by employing the models of Ordinary Least Squares multiple regression (providing global and spatially stationary results) and the Geographically Weighted Regression (presenting spatially varying coefficients). Results point to the central area of the city as priority to implement strategies from the IUWM. The estimation provides a deeper comprehension of water crisis in Mexico City from a water demand-side view, it is also useful for decision-making.

Keywords: Urban residential water demand, spatial analysis, integrated urban water management, Mexico City, geographically weighted regression. 


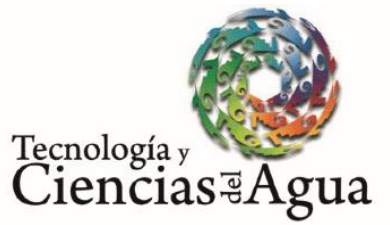

2021, Instituto Mexicano de Tecnología del Agua

Open Access bajo la licencia CC BY-NC-SA 4.0

(https://creativecommons.org/licenses/by-nc-sa/4.0/)

\section{Resumen}

La gestión del agua en las ciudades se ha vuelto cada más desafiante debido al aumento de la demanda urbana de agua en un contexto de reducción de las fuentes disponibles. Estos problemas han evidenciado la necesidad de integrar el abastecimiento de agua, drenaje y saneamiento desde el paradigma de la Gestión Integrada del Agua Urbana (GIAU). Para el estudio del componente de abastecimiento es importante considerar el análisis de los determinantes de la demanda urbana de agua. En el caso de la Ciudad de México, no se cuenta con un diagnóstico certero de dichos determinantes, a pesar de que enfrenta múltiples problemas en materia hídrica. Por esta razón, el objetivo de este trabajo consiste en estimar la demanda doméstica de agua y sus determinantes en la Ciudad de México a escala de colonias para el año 2010, con base en datos oficiales medidos. Los determinantes analizados se relacionan con cuestiones socioeconómicas, densidad urbana y acceso al agua; se usaron los modelos de regresión múltiple de mínimos cuadrados (que provee resultados globales y espacialmente estacionarios), y de regresión geográficamente ajustada (que presenta coeficientes que varían de forma espacial). Los resultados señalan que el área central de la ciudad es prioritaria para implementar estrategias desde la GIAU. La estimación presentada aporta a una comprensión más profunda de la crisis de agua en la Ciudad de México desde la visión de la demanda de agua, además de ser útil para la toma de decisiones.

Palabras clave: demanda doméstica de agua, análisis espacial, gestión integrada del agua urbana, Ciudad de México, regresión geográficamente ajustada. 


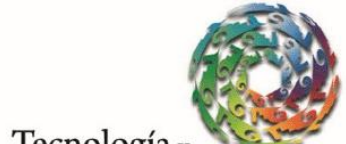 \\ Tecnología y \\ Ciencias $₫$ Agua}

Received: $17 / 12 / 2019$

Accepted: 24/06/2020
2021, Instituto Mexicano de Tecnología del Agua

Open Access bajo la licencia CC BY-NC-SA 4.0

(https://creativecommons.org/licenses/by-nc-sa/4.0/)

\section{Introduction}

Cities around the world are facing challenges to managing water resources since freshwater sources are diminishing, droughts as well as other hydrometeorological extreme events are increasing their frequency, causing the development of new supplies to become environmentally and politically unfeasible (Baumann \& Boland, 1998). These challenges are related to a constant escalation of urban water demand (Saurí, 2013), linked to the growing population residing in cities that represents half of the world's population (UN, 2018). Integrated Urban Water Management (IUWM) emerged as an alternative paradigm to tackle these issues by integrating three components of urban water services: supply, drainage, and sanitation. IUWM seeks to integrate land-use planning and economic development to overcome fragmentation in public policy formulation to accomplish economic, social, and environmental goals (Bahri, 2011). This paradigm carries out sustainable development within the urban water sector (Tiburcio \& Perevochtchikova, 2012).

IUWM is a demand-side paradigm that conceives water needs to be multifaceted and not merely a question of quantity, in contrast to the 


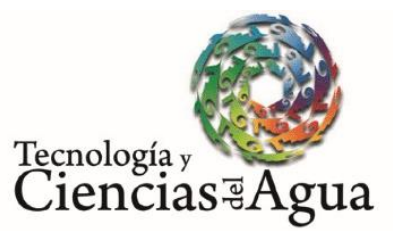

traditional water management paradigm (Mitchell, 2006). Therefore, all water uses are considered, as well as quality and quantity for final uses (Pinkham, 1999). These conceptions target the supply component of IUWM, highlighting the need to balance water supply and demand by focusing on reducing water uses and losses, including unaccounted water in a system (Baumann \& Boland, 1998). The goals of this balance are meeting human and ecosystem needs, in addition to selecting the most efficient options to manage water (Saurí, 2013; Chang, 2017). Urban water demand takes place in natural and social systems at different temporal and spatial scales with different dynamics (House-Peters \& Chang, 2011). Both systems must be considered to attain the integration of water management components (Tiburcio \& Perevochtchikova, 2012).

Different micro and macro-scale urban water demand determinants have been identified in case studies from Australia, Europe, and the United States (Worthington \& Hoffman, 2008; March \& Saurí, 2009). In contrast, case studies from urban areas of developing countries are still lacking (Saurí, 2013). In Latin America just two studies were found, one in the City of Fortaleza, Brazil (De-Maria-André \& Carvalho, 2014), and the other for the City of Hermosillo in Mexico (Ojeda, Álvarez, Ramos, \& Soto, 2017).

One macro-scale determinant of residential water use is urban density (Chang, 2017), which has been found to reduce water use (Saurí, 2013). Case studies carried out in the cities of Austin, Phoenix, Portland, and Salt Lake City are evidence of this statement (Chang, Hossein, \& Shandas, 2010; Shandas \& Parandvash, 2010; Stoker et al., 2019). Similar evidence was found in the city of Auckland, New Zealand (Ghavidelfar \& Shamseldin, 2017). In these cases, urban density is 


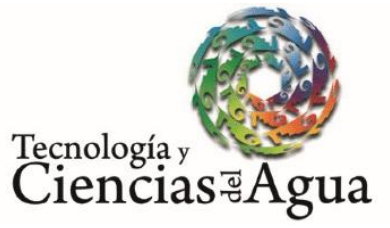

2021, Instituto Mexicano de Tecnología del Agua

Open Access bajo la licencia CC BY-NC-SA 4.0

(https://creativecommons.org/licenses/by-nc-sa/4.0/)

negatively associated with water use, while the presence of gardens and pools tend to increase it, as both are typical characteristics of low urban density dwellings (Domene \& Saurí, 2006; Wentz \& Gober, 2007; DeMaria-André \& Carvalho, 2014; Kontokosta \& Jain, 2015).

Income and household size are the most mentioned socioeconomic determinants of water use, which typically are positively related (Arbués, García-Valiñas, \& Martínez-Espiñeira, 2003; Arbués \& Villanúa, 2006; Domene \& Saurí, 2006; Wentz \& Gober, 2007; Worthington \& Hoffman, 2008; De-Maria-André \& Carvalho, 2014; Kontokosta \& Jain, 2015). Some other relevant determinants have been studied, such as inhabitants with college education and the number of internal water connections (Babel, Das Gupta, \& Pradhan, 2007); race and ethnicity, and land use regulation (Turner \& Ibes, 2011); gender and the number of bathrooms (De-MariaAndré \& Carvalho, 2014; Ojeda et al., 2017); and energy consumption (Kontokosta \& Jain, 2015). It is relevant to consider the role of water measurement, as it reduces residential water demand (Worthington \& Hoffman, 2008). Evidence on this point has been found in three Californian cities (Tanverakul \& Lee, 2015), as well as in the city of Hermosillo, Mexico (Ojeda et al., 2017).

Different temporal and spatial scales have been used in all these studies, ranging from parcels to city level, and also from daily to annual time series. Depending on the target of required actions, spatial and temporal scales are chosen, as determinants of water demand vary over space and time (Billings \& Jones, 2008; Chang, 2017). Spatial research on urban water demand has increased since 2001; it has allowed to understand the roles of location and adjacency to explain water use (House-Peters \& Chang, 2011). 


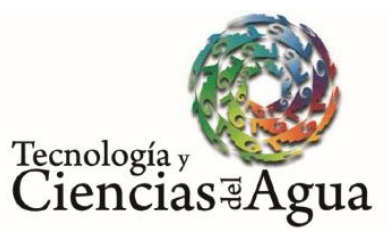

Some studies have used spatial lag and spatial error regression analyses with units such census tracts (Chang et al., 2010; House-Peters, Pratt, \& Chang, 2010; Chang, Bonnette, Stoker, Crow-Miller, \& Wentz, 2017; Stoker et al., 2019). These two analyses are spatially stationary and global. In turn, Geographically Weighted Regression (GWR) is a spatially explicit non-stationary local analysis that approaches varying spatial relationships among variables, giving local statistics for each spatial unit under study (Fotheringham, Brunsdon, \& Charlton, 2002). GWR has been employed to estimate local coefficients associating water consumption to different single family residential variables, across census tracts in Phoenix (Wentz \& Gober, 2007). This analysis has also been used with multi-family residential water use in New York City (Kontokosta \& Jain, 2015).

As previously mentioned, urban water demand determinants have been lightly studied in Latin America; this is the case of Mexico City, one of the megacities of this region and the capital of Mexico (Perevochtchikova, 2015). The relevance of studying these determinants, emerge as the city is lacking a precise diagnosis on this topic (GDF, 2007; GDF, 2012), while demand has been found to be a pressure over groundwater resources which threatens the long term sustainability of the city (Martínez, Escolero, \& Perevochtchikova, 2015). Summarizing, the city has been facing multiple challenges such as vulnerable water supply infrastructure (Escolero, Kraslisch, Martínez, \& Perevochtchikova, 2016), social and political conflicts (Perló \& González, 2009), water shortages and intermittent water supply (Morales \& Rodríguez, 2009), as well as varying access to water services (Jiménez, Gutiérrez, Marañón, \& González, 2011). Comprehending the demand-side of water management 


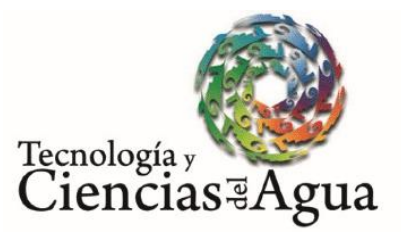

2021, Instituto Mexicano de Tecnología del Agua

Open Access bajo la licencia CC BY-NC-SA 4.0

(https://creativecommons.org/licenses/by-nc-sa/4.0/)

is the first step towards the development of water conservation strategies applying IUWM principles.

In this sense, the present study proposes the analysis and estimation of residential water demand for the year 2010 in Mexico City based on a local scale, considering socioeconomic, urban density, and access to water services determinants applying two models: one global and stationary and the other local, spatially explicit and non-stationary. The contribution of this work consists in proposing a useful tool to better comprehend the complex water crisis of Mexico City from a water demand-side view, as well as to advice the decision-making process from the IUWM principals.

\section{Water Management in Mexico City}

Mexico City has 8.85 million inhabitants, it spreads over an area of 7854 km² housing 22815504 people (INEGI, 2012). This urban complex is located inside the Hydrological Administrative Region (HAR) XIII "Waters of the Valley of Mexico" in terms of national water management (Figure 1). The HAR XIII presents the highest degree of pressure over water resources (141\%), and has the lowest annual water availability of the country with $144 \mathrm{~m}^{3}$ per person. Mexico City generates $16.97 \%$ of the 
national Gross Domestic Product (GDP), while its per capita water availability is only $55 \mathrm{~m}^{3}$ (Conagua, 2018). 


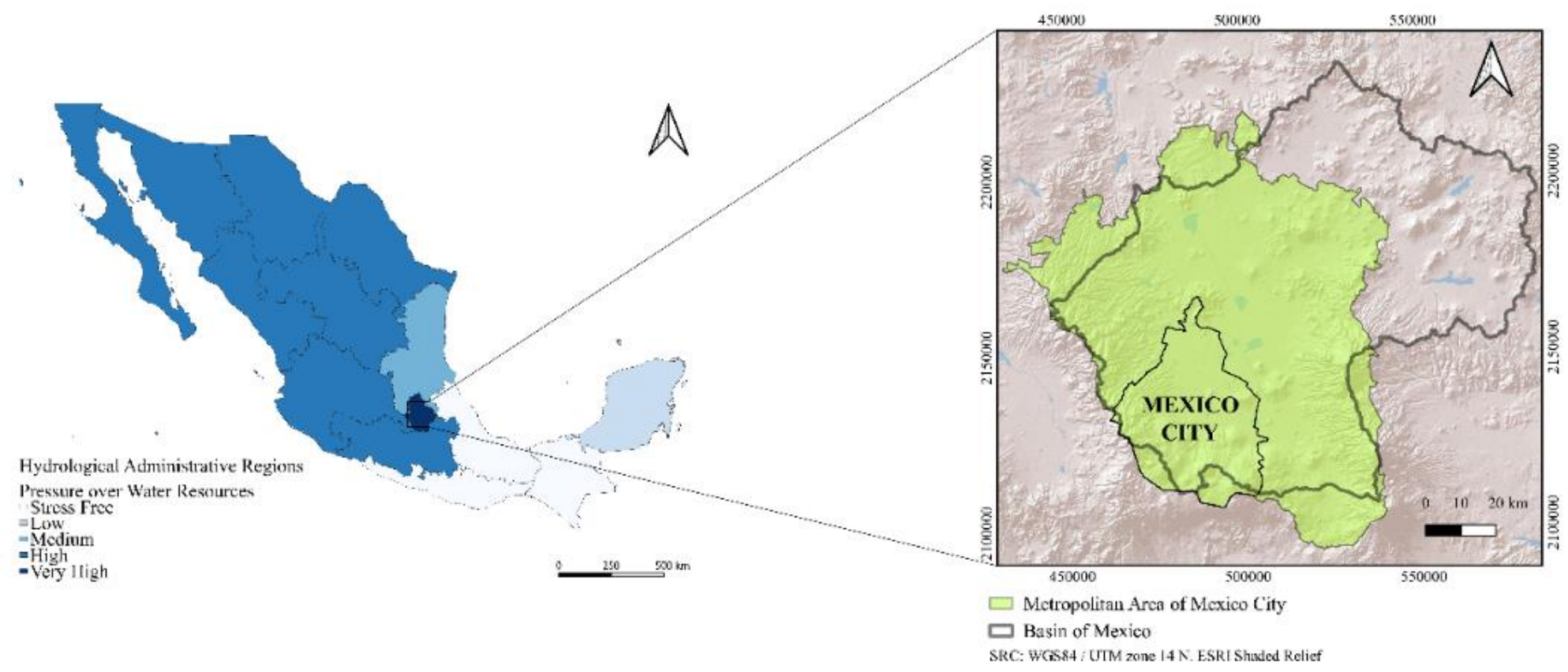

Water Supply Infrastructure to Mexico City

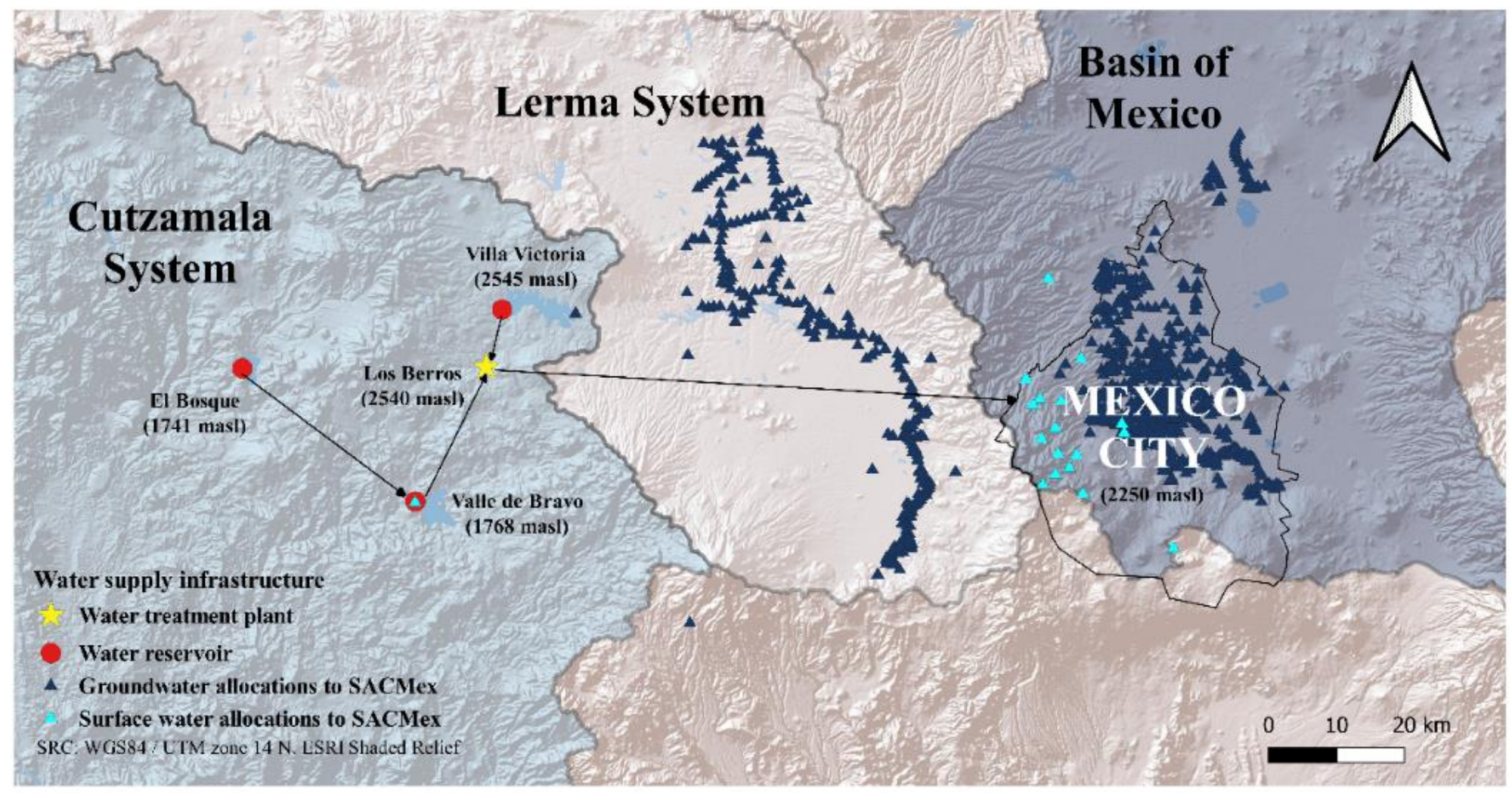




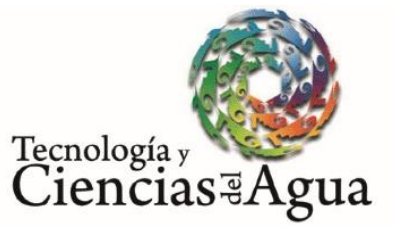

2021, Instituto Mexicano de Tecnología del Agua

Open Access bajo la licencia CC BY-NC-SA 4.0

(https://creativecommons.org/licenses/by-nc-sa/4.0/)

Figure 1. Mexico City location (Source: self-elaborated with data from INEGI (2012); Conagua (2018) and information form Conagua website https://app.conagua.gob.mx/consultarepda.aspx).

Water management in Mexico City is complex, as it involves actions from different institutions at national and local levels (Perevochtchikova, 2015). The Mexican National Water Commission (Conagua, abbreviation in Spanish) is a federal institution in charge of allocating permits on water volumes to the national water users (Conagua, 2009); while the Waters System of Mexico City (Sistema de Aguas de la Ciudad de México, abbreviation in Spanish: Sacmex) is the local water utility in charge of providing water services in Mexico City (ALDF, 2003). Sacmex is a national water user under Conagua regulation. Both insitutions are involved in Mexico City water supply, as infrastructure (Figure 1) links artificially three different basins (Cutzamala, Lerma and the Basin of Mexico). Average water supply for the period $2008-2013$ was $31.33 \mathrm{~m}^{3} / \mathrm{s}$ (Sacmex, 2014b), it was withdrawn from different surface and groundwater sources that are managed by either Conagua or Sacmex as Table 1 summarizes. Groundwater from inside Mexico City's territory is the most important source, the remaining water quantity is obtained from distant sources. 
Table 1. Water supply to Mexico City for the 2008-2013 period. Source: self-elaborated with data obtained from the transparency portal of Sacmex (2014b) y Sacmex (2016).

\begin{tabular}{|c|c|c|c|c|c|c|}
\hline Basin & Institution & Source & Location & $\begin{array}{l}\text { Supply } \\
\text { System }\end{array}$ & $\begin{array}{c}\text { Average } \\
\text { supply } \\
\left(\mathrm{m}^{3} / \mathrm{s}\right)\end{array}$ & $\begin{array}{c}\text { Supply } \\
\text { contribution } \\
(\%)\end{array}$ \\
\hline \multirow{4}{*}{$\begin{array}{l}\text { Basin of } \\
\text { Mexico }\end{array}$} & \multirow[t]{3}{*}{ Sacmex } & Groundwater & \multirow[t]{2}{*}{ Mexico City } & $\begin{array}{l}\text { Center } \\
\text { East } \\
\text { North } \\
\text { South } \\
\text { West }\end{array}$ & $\begin{array}{l}1.93 \\
2.51 \\
1.07 \\
8.02 \\
0.21\end{array}$ & $\begin{array}{c}6.15 \\
8.00 \\
3.41 \\
25.61 \\
0.66\end{array}$ \\
\hline & & $\begin{array}{c}\text { Surface } \\
\text { water }\end{array}$ & & \begin{tabular}{|l} 
Magdalena \\
River \\
Springs
\end{tabular} & $\begin{array}{l}0.20 \\
0.76\end{array}$ & $\begin{array}{l}0.62 \\
2.42\end{array}$ \\
\hline & & Groundwater & \multirow{4}{*}{$\begin{array}{l}\text { State of } \\
\text { Mexico }\end{array}$} & Chiconautla & 1.42 & 4.53 \\
\hline & Conagua & Groundwater & & $\begin{array}{l}\text { Chalmita } \\
\text { La Caldera }\end{array}$ & $\begin{array}{l}2.01 \\
0.52\end{array}$ & $\begin{array}{l}6.42 \\
1.66\end{array}$ \\
\hline Cutzamala & Conagua & $\begin{array}{c}\text { Surface } \\
\text { water }\end{array}$ & & Cutzamala & 8.60 & 27.43 \\
\hline Lerma & Sacmex & Groundwater & & Lerma & 4.10 & 13.08 \\
\hline
\end{tabular}

The Lerma and Cutzamala Systems were built during the $20^{\text {th }}$ century to deal with the increasing population water needs of Mexico City, as well as to diminish land subsidence inside the Basin of Mexico due to groundwater extraction (Perló \& González, 2009). This situation pictures the traditional water management paradigm, as decisions were taken by 


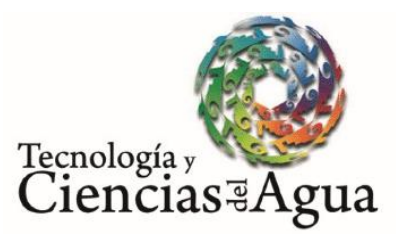

2021, Instituto Mexicano de Tecnología del Agua

Open Access bajo la licencia CC BY-NC-SA 4.0

(https://creativecommons.org/licenses/by-nc-sa/4.0/)

only conceiving water demand in terms of population growth (Tiburcio \& Perevochtchikova, 2012), which increased from 0.37 million people in 1900 to 8.85 million in 2010 (GDF, 2012; INEGI, 2012). Despite these efforts, all water supply systems are currently working under high restrictions, being the Cutzamala System the most vulnerable water source (Escolero et al., 2016), while local groundwater extraction is causing severe drawdowns of potentiometric levels in the Basin of Mexico (Martínez et al., 2015).

Besides this issue Morales and Rodríguez (2009), based on Conagua Water Statistics in Mexico bulletin of 2004, mention the existence of a $10.24 \mathrm{~m}^{3} / \mathrm{s}$ water deficit between natural water availability and allocated quantity that causes water restrictions and intermittent water supply (tandeo in Spanish) across the city. In parallel, according to Jiménez et al. (2011) access to water services does not spread evenly in Mexico City. These authors define the most proficient level of access to water services as a 24 hour serving internal water connection, with highly drinkable water quality. Water losses are another relevant issue since around $40 \%$ of Mexico City water supply is estimated to be lost due to leakage (Perló \& González, 2009; GDF, 2012; Sacmex, 2019).

In addition, since 1994 the local government has focused on increasing water demand measurement (Martínez, 2004), but this target has not been fully accomplished. Average water measurement coverage for the period 2008-2013 ranged for $63 \%$ of residential water users, $70 \%$ for non-residential users, and $82 \%$ for the mixed water use (Sacmex, 2014a). These users refer to a person hiring water services from Sacmex according to the local legislation (ALDF, 2003). Based on the 2010 national census data from the National Institute of Statistics and 
Geography (INEGI), 2.4 million dwellings were reported to have an internal water connection, while Sacmex counted 2 million residential water users, out of which 1.29 million had a metering device (GDF, 2012: $35)$. For the year $2010,64.25 \%$ of residential water users had a metering device generating $9.95 \mathrm{~m}^{3} / \mathrm{s}$ of residential water demand (Sacmex, 2014a). Figure 2 shows a comparison of water supply and metered water uses for the period 2008-2013.

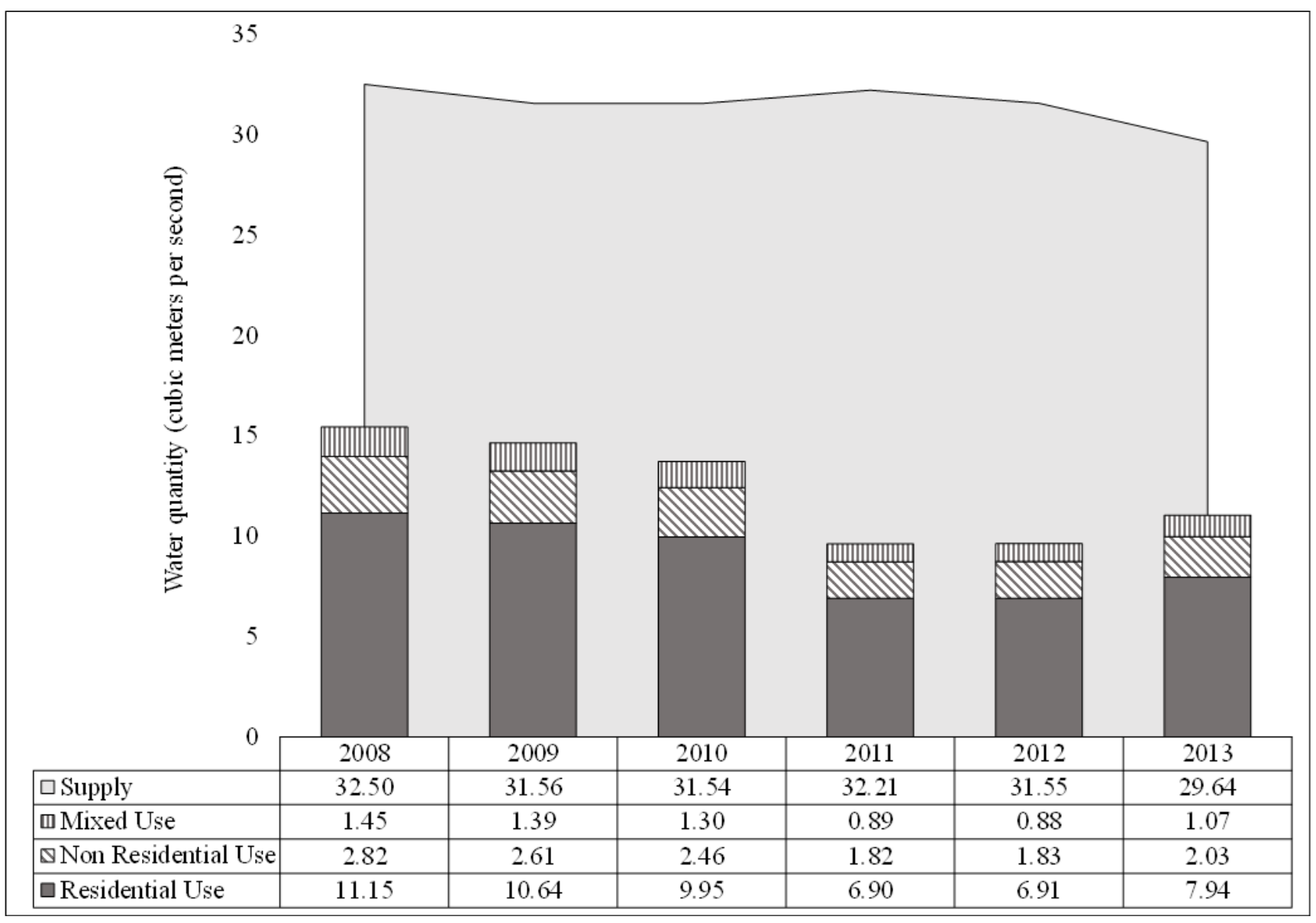

Figure 2. Water uses and water supply in Mexico City, 2008-2013.

Source: self-elaborated with data obtained from the transparency portal of Sacmex (2014a) and Sacmex (2014b). 


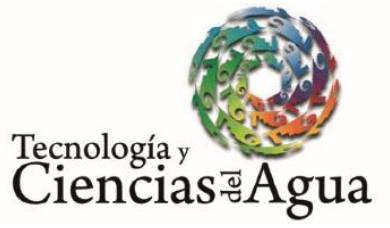

2021, Instituto Mexicano de Tecnología del Agua

Open Access bajo la licencia CC BY-NC-SA 4.0

(https://creativecommons.org/licenses/by-nc-sa/4.0/)

Although the IUWM principles have been introduced as a guideline for Sacmex, the local governmental programs mainly focus on infrastructure development strategies (ALDF, 2003; GDF， 2012). Particularly, water demand is mainly considered an issue of population growth and no other determinant or diagnosis is given (GDF, 2012). In contrast, population growth in the city has been showing a stabilizing trend that is projected to decrease until 2030 (Downs, Mazari-Hiriart, Domínguez-Mora, \& Suffet, 2000; Perló \& González, 2009; Conagua, 2018). This highlights the relevance of approaching water demand determinants other than population growth to understand residential water demand comprehensively.

Water demand in Mexico City has been lightly studied in comparison to other topics around water management. Downs et al. (2000) forecasted water demand for the whole Metropolitan Area of Mexico City until 2015, based on a probabilistic model of population growth extrapolating some socioeconomic characteristics of one district (alcaldía in Spanish) within the city. Their results accounted for $26 \mathrm{~m}^{3} / \mathrm{s}$ in Mexico City, which is similar to an estimation of $22.3 \mathrm{~m}^{3} / \mathrm{s}$ reported by Sacmex in GDF (2007:13). In addition, per capita water use correlates positively with socioeconomic variables and negatively to household size (Montesillo, 2004; Dávila \& Constantino, 2007). These studies were performed at a municipality and district level comprising huge spatial heterogeneity; on the other hand, the use of measured data is not mentioned either. In contrast, Ramos-Bueno (2016) analyzed measured data of residential water demand on a neighborhood scale. However, this study is still limited 

2021, Instituto Mexicano de Tecnología del Agua
Open Access bajo la licencia CC BY-NC-SA 4.0
Tecnología y
(https://creativecommons.org/licenses/by-nc-sa/4.0/)

as intermittent water supply was not included and also global spatially stationary techniques were used.

\section{Data and methods}

Water demand is defined as "the total volume of water necessary or needed to supply customers within a certain period of time" (Billings \& Jones, 2008: 4). In this context, empirical studies referring to either residential water demand (Downs et al., 2000; Arbués \& Villanúa, 2006; Babel et al., 2007; Wentz \& Gober, 2007; Shandas \& Parandvash, 2010; Turner \& Ibes, 2011; De-Maria-André \& Carvalho, 2014; Ashoori, Dzombak, \& Small, 2016; Ghavidelfar \& Shamseldin, 2017); water consumption (Domene \& Saurí, 2006; Chang et al., 2010; House-Peters et al., 2010; Ojeda et al., 2017); or water use (Kontokosta \& Jain, 2015; Chang et al., 2017), are used interchangeably. The present study uses the term residential water demand which corresponds to measured residential water use during 2010.

\section{Statistical analysis}




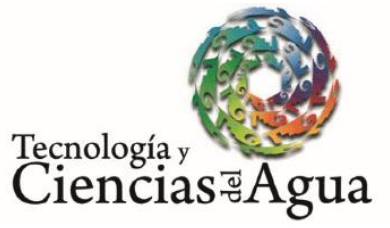

2021, Instituto Mexicano de Tecnología del Agua

Open Access bajo la licencia CC BY-NC-SA 4.0

(https://creativecommons.org/licenses/by-nc-sa/4.0/)

The Ordinary Least Squares (OLS) multiple regression and Geographically Weighted Regression (GWR) models, were used to estimate residential water demand and determinants in Mexico City neighborhoods. Both models were compared similarly to the studies of Wentz and Gober (2007) for the case of Phoenix, and Kontokosta and Jain (2015) in New York City. For this, the first step consisted on creating a correlation matrix among all variables to check their signs and magnitudes; this procedure was used to reduce possible multicollinearity issues (Babel et al., 2007; Billings \& Jones, 2008; Chang et al., 2010).

After exploring these relationships, the univariate spatial autocorrelation analyses were carried out by measuring the Moran's I index to address the propagation of each variable under study. When this index has a positive value, it shows the existence of spatial clustering while a negative value denotes spatial dispersion; zero is a non existant spatial pattern (Buzai \& Baxendale, 2012). To locate clusters of high and low values for each variable, the Local Indicators of Spatial Association (LISA) analysis was performed in GeoDa 1.12.1.1 software (https://spatial.uchicago.edu/geoda) (Anselin, 2005). A Queen Contiguity matrix was selected for the spatial weighting, as it considers edge or vertex of the spatial units as neighbors (Chang et al., 2017).

The OLS multiple regression analysis was used to estimate coefficients of residential water demand based on a set of independent variables (Burt, Barber, \& Rigby, 2009; Buzai \& Baxendale, 2012). Although this type of analysis has previously been used with spatial units (Wentz \& Gober, 2007; Chang et al., 2010; House-Peters et al., 2010; 

Tecnología y
Ciencias đAgua
2021, Instituto Mexicano de Tecnología del Agua
Open Access bajo la licencia CC BY-NC-SA 4.0
(https://creativecommons.org/licenses/by-nc-sa/4.0/)

Chang et al., 2017); its results are global and spatially stationary and also tend to violate the assumption of variables independence since spatial phenomena usually show spatial autocorrelation (Fotheringham et al., 2002). To address this issue, a univariate spatial autocorrelation analysis was carried out with the OLS residuals, calculating the Moran's I index (Buzai \& Baxendale, 2012). The general OLS multiple regresion model is specified as follows:

$$
y_{i}=\beta_{0}+\sum_{k} \beta_{k} X_{k}+\varepsilon
$$

Where $(y)$ is the dependent variable, $(x)$ is one or more independent variables, and $(\varepsilon)$ is the error term. The $(\beta)$ coefficients are the contributions of each independent variable to the prediction of the dependent variable (Burt et al., 2009).

Fotheringham et al. (2002) proposed the GWR model which provides $\beta$ coefficients, standard errors, t-scores, and $R^{2}$ at each location under study, as it explores the spatial variation of the independent determinants over the dependent variable, this means it is a local spatially explicit non-stationary model. The general model specification is given by:

$\mathrm{y}_{\mathrm{i}}=\beta_{0}\left(\mathrm{u}_{\mathrm{i}}, \mathrm{v}_{\mathrm{i}}\right)+\sum_{\mathrm{k}} \beta_{\mathrm{k}}\left(\mathrm{u}_{\mathrm{i}}, \mathrm{v}_{\mathrm{i}}\right) \mathrm{x}_{\mathrm{ik}}+\varepsilon_{\mathrm{i}}$

(Equation 2)

This model presents the term $\left(u_{i}, v_{i}\right)$ that denotes the geographical coordinates of the ith point in space; this is an addition to the OLS multiple regression (Fotheringham et al., 2002). The GWR model was used to 


\section{(6) \\ Tecnología y \\ Ciencias $\approx$ Agua}

2021, Instituto Mexicano de Tecnología del Agua

Open Access bajo la licencia CC BY-NC-SA 4.0

(https://creativecommons.org/licenses/by-nc-sa/4.0/)

estimate annual residential water demand in Mexico City, using GWR4.0 software (https://sgsup.asu.edu/sparc/gwr4). An adaptative bi-square kernel was selected to calculate the distance bandwidth of the model to obtain local statistics. Coefficients of both models were estimated using a log-log form, which enables to obtain elasticities of residential water demand (Agthe \& Billings, 2003; Billings \& Jones, 2008). Additionally, the GWR model allowed to estimate local elasticities of residential water demand addressing their spatial variation. All the independent variables were analyzed according to their resultant spatial clusters form the GWR analysis.

After estimating coefficients from both models, they were compared by the Akaike Information Criterion (AIC), as well as their $R^{2}$ values to exmine their accuracy and their explanation capacity (Fotheringham et al., 2002; Anselin, 2005). Predicted results obtained from both analyses were compared to observed data (stemming from residential water users with metering device). Then, predicted results were adedd separately to unaccounted residential water quantity (calculated employing users without metering device) to generate two estimations of residential water demand for the whole city.

\section{Independent variables selection}


All data were assembled at the neighborhood scale (colonias, in Spanish and in the Mexico City context), as the unit of spatial analysis. A shapefile depicting 1456 neighborhoods was provided by the local Ministry of Urban Development and Dwellings (Seduvi, 2014). The year 2010 was selected due to Census data availability (INEGI, 2012). Neighborhoods without residential water use, those having zero consumption and lack of water measurement coverage were labeled as excluded polygons. The final study area consisted of 1346 neighborhoods in Mexico City.

Total annual residential water demand per neighborhood for 2010 was selected as the dependent variable. Six variables were chosen as explanatory (independent) variables or determinants based on literature review. Therefore, socioeconomic factors, urban density, and two characteristics concerning access to water services were included. Table 2 summarizes the type of determinants, units, data sources, and the previous international studies which supported this selection.

Table 2. Determinants of residential water demand in Mexico City.

\begin{tabular}{|l|l|l|l|l|}
\hline \multicolumn{1}{|c|}{$\begin{array}{c}\text { Independent } \\
\text { variable }\end{array}$} & $\begin{array}{c}\text { Type of } \\
\text { determinant }\end{array}$ & \multicolumn{1}{|c|}{ Units } & \multicolumn{1}{c|}{ Data source } & \multicolumn{1}{c|}{$\begin{array}{c}\text { Previous } \\
\text { international studies }\end{array}$} \\
\hline $\begin{array}{l}\text { Residential water } \\
\text { users with } \\
\text { metering device }\end{array}$ & $\begin{array}{l}\text { Control } \\
\text { variable }\end{array}$ & $\begin{array}{l}\text { Percentage } \\
\text { of users } \\
\text { with } \\
\text { metering } \\
\text { device }\end{array}$ & Sacmex (2014a) & $\begin{array}{l}\text { Martínez (2004); } \\
\text { Tanverakul and Lee } \\
(2015) ; \text { Ojeda et al. } \\
(2017)\end{array}$ \\
\hline $\begin{array}{l}\text { Social } \\
\text { Development Index }\end{array}$ & Socioeconomic & $\begin{array}{l}\text { Average } \\
\text { IDS, it } \\
\text { ranges from }\end{array}$ & $\begin{array}{l}\text { Evalúa CDMX } \\
\text { (2016) }\end{array}$ & $\begin{array}{l}\text { Arbués and Villanúa } \\
\text { (2006); Domene and } \\
\text { Saurí (2006); Shandas }\end{array}$ \\
\cline { 2 - 5 }
\end{tabular}




\begin{tabular}{|c|c|c|c|c|}
\hline & & $\begin{array}{l}0 \text { to } 1 \text {, } \\
\text { where one } \\
\text { is optimum }\end{array}$ & & $\begin{array}{l}\text { and Parandvash } \\
\text { (2010); Turner and } \\
\text { Ibes (2011); De-Maria- } \\
\text { André and Carvalho } \\
(2014) \text {; Kontokosta } \\
\text { and Jain (2015); } \\
\text { Ashoori et al. (2016) }\end{array}$ \\
\hline Household Size & & $\begin{array}{l}\text { Persons per } \\
\text { dwelling }\end{array}$ & INEGI (2012) & $\begin{array}{l}\text { Arbués and Villanúa } \\
\text { (2006); Domene and } \\
\text { Saurí (2006); Wentz } \\
\text { and Gober (2007); } \\
\text { Turner and Ibes } \\
\text { (2011); Kontokosta } \\
\text { and Jain (2015) }\end{array}$ \\
\hline Dwelling density & Urban density & $\begin{array}{l}\text { Dwellings } \\
\text { per hectare }\end{array}$ & INEGI (2012) & $\begin{array}{l}\text { Chang et al. (2010); } \\
\text { Shandas and } \\
\text { Parandvash (2010); } \\
\text { Ghavidelfar and } \\
\text { Shamseldin (2017); } \\
\text { Stoker et al. (2019) }\end{array}$ \\
\hline $\begin{array}{l}\text { Dwellings with } \\
\text { internal water } \\
\text { connection }\end{array}$ & \begin{tabular}{|l} 
\\
Access to \\
water services
\end{tabular} & $\begin{array}{l}\text { Total } \\
\text { dwellings } \\
\text { with } \\
\text { internal } \\
\text { water } \\
\text { connection }\end{array}$ & INEGI (2012) & Babel et al. (2007) \\
\hline $\begin{array}{l}\text { Intermittent water } \\
\text { supply (Tandeo) }\end{array}$ & & $\begin{array}{l}\text { Dummy } \\
\text { variable } 1 \\
\text { when }\end{array}$ & $\begin{array}{l}\text { Official } \\
\text { Newspaper } \\
\text { CDMX, GDF } \\
(2010)\end{array}$ & Jiménez et al. (2011) \\
\hline
\end{tabular}




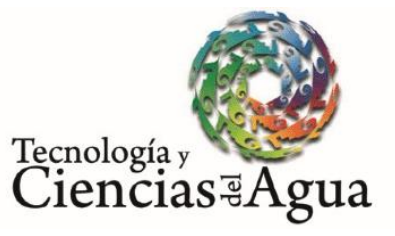

Residential water users with metering device were selected as an independent control variable, due to the high levels of unaccounted water use. Total dwellings with internal water connection were considered as an access to water services variable, characterizing $88.14 \%$ of dwellings in the city (Jiménez et al., 2011). These two variables are relevant to contrast in terms of differences between Sacmex and INEGI counts on the topic (GDF, 2012).

Regarding another dimension of access to water services, Jiménez et al. (2011) mention that $81.5 \%$ of the city inhabitants have daily water provision. Therefore, it is relevant to explore the role of intermittent water supply in relation to water demand. This issue was addressed using data from the local official government newspaper of Mexico City (Gaceta Oficial $(D M X)$, as neighborhoods with this type of supply are listed there (GDF, 2010). Household size is a well-known determinant of water demand, usually having an increasing effect. According to Wentz and Gober (2007), based on Mayer et al. (1999), it is a good proxy of indoor water uses.

The Social Development Index is a local government measure, created to grant universal coverage of human rights and to locate social policy actions needed in the city. For this case, it was used as a proxy for income. Sánchez, Boltvinik, Ruiz and Figueroa (2011) expose the methodological approach used for its creation, where six different sources of well being are synthesized and summarized: (1) current income, (2) access to public services, (3) property ownership, (4) educational level, 
(5) time availability for recreation, and (6) capacity to acquire debt. This index is measured per parcel. Finally, dwelling density was addressed as higher density tends to reduce water demand (March \& Saurí, 2009; Saurí, 2013; Chang, 2017).

\section{Results}

Descriptive statistics of input variables appear in Table 3; they show data transformed into logarithmic form.

Table 3. Descriptive statistics in logarithmic form of the dependent and independent variables selected to analyze residential water demand in Mexico City, 2010.

\begin{tabular}{|l|c|c|c|c|}
\hline \multicolumn{1}{|c|}{ Variable } & Minimum & Maximum & Mean & $\begin{array}{l}\text { Standard } \\
\text { deviation }\end{array}$ \\
\hline $\begin{array}{l}\text { Annual residential } \\
\text { water demand (cubic } \\
\text { meters) }\end{array}$ & 2.91 & 15.09 & 11.53 & 1.57 \\
\hline $\begin{array}{l}\text { Residential water users } \\
\text { with metering device } \\
(\%)\end{array}$ & -3.06 & 4.61 & 4.07 & 0.89 \\
\hline
\end{tabular}


Ciencias $₫$ Agua

\begin{tabular}{|l|c|c|c|c|}
$\begin{array}{l}\text { Total dwellings with } \\
\text { internal water }\end{array}$ & 2.44 & 10.05 & 6.82 & 1.11 \\
\hline $\begin{array}{l}\text { Average Social } \\
\text { Development Index }\end{array}$ & -0.63 & 0.00 & -0.21 & 0.12 \\
\hline $\begin{array}{l}\text { Intermittent water } \\
\text { supply (0 or 1) }\end{array}$ & 0.00 & 1.00 & 0.10 & 0.29 \\
\hline $\begin{array}{l}\text { Average household size } \\
\text { (inhabitants per } \\
\text { dwelling) }\end{array}$ & 0.76 & 1.68 & 1.29 & 0.13 \\
\hline $\begin{array}{l}\text { Dwelling density } \\
\text { (dwellings per ha) }\end{array}$ & -1.52 & 4.92 & 3.54 & 0.74 \\
\hline
\end{tabular}

\section{Correlation matrix and variables spatial distribution}

Figure 3 shows the correlation matrix of all variables, which are significantly correlated to the dependent variable. Dwellings with internal water connection (VA) and residential water demand (AN) are strongly and positively correlated. Household size $(\mathrm{TH})$ and intermittent water supply (TA) exhibit negative signs, showing an inverse correlation with residential water demand. The highest sign of the whole matrix is between the Social Development Index (ID) and household size. To avoid multicollinearity issues household size was excluded from the OLS and 
GWR analyses, remaining just five independent variables for these procedures. It is relevant to notice the negative sign of this correlation.

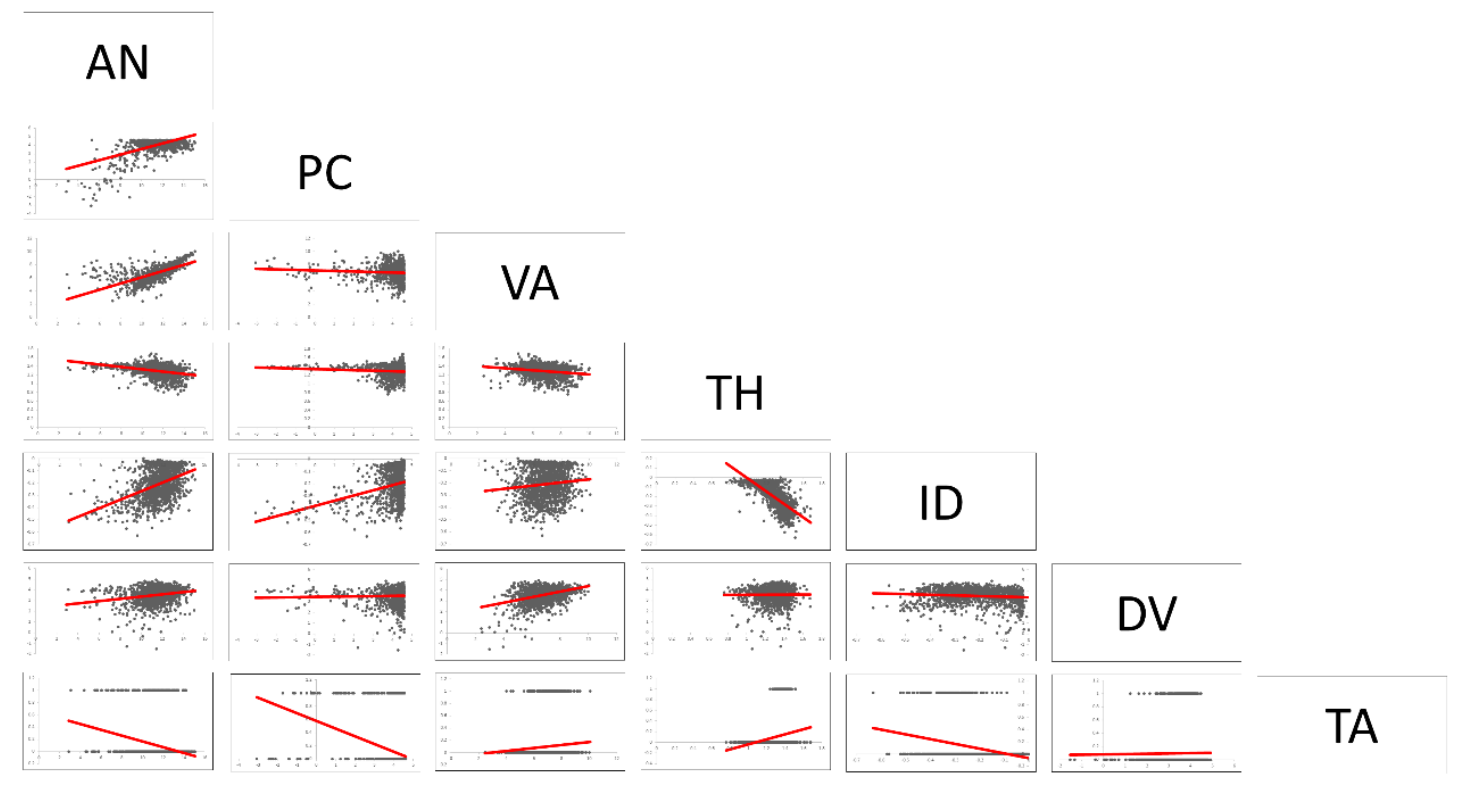

Figure 3. Correlation matrix between all variables under analysis:

Annual residential water demand (AN), residential users with metering device (PC), total dwellings with internal water connection (VA), average Social Development Index (ID), intermittent water supply (TA), household size (TH) and dwelling density (DV).

The LISA analyses for the dependent variable and the five remaining input variables appear in Figure 4. Results from the Moran's I index were positive values ranging from 0.34 to 0.65 ; this indicates that the variables under study present significant spatial patterns across the city 
neighborhoods. Maps locating high and low values of each variable appear in dark red and light blue, respectively. 
Tecnología y

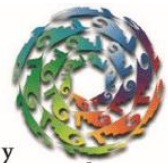

Ciencias $\asymp$ Agua
2021, Instituto Mexicano de Tecnología del Agua

Open Access bajo la licencia CC BY-NC-SA 4.0

(https://creativecommons.org/licenses/by-nc-sa/4.0/)
A) Annual Residential Water

Demand

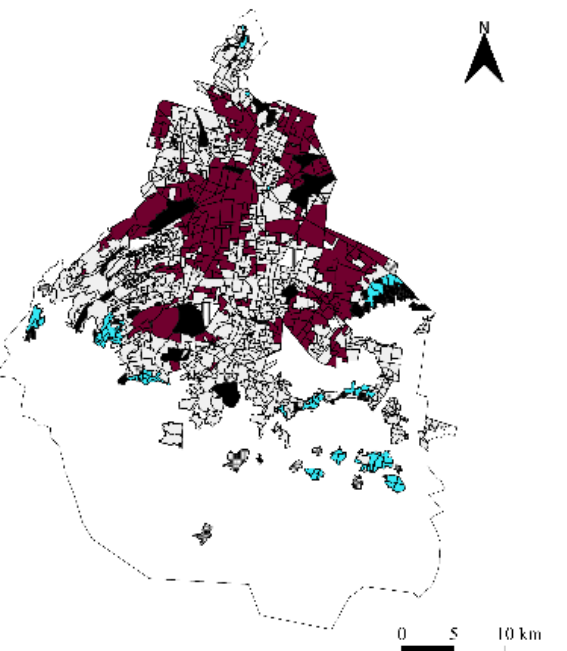

Local Indicators of Spatial Association

$\neg$ Not Significant

-High-High

$\neg$ Low-Low

कHigh-Low

aNighborless

- ExcTuded polygons

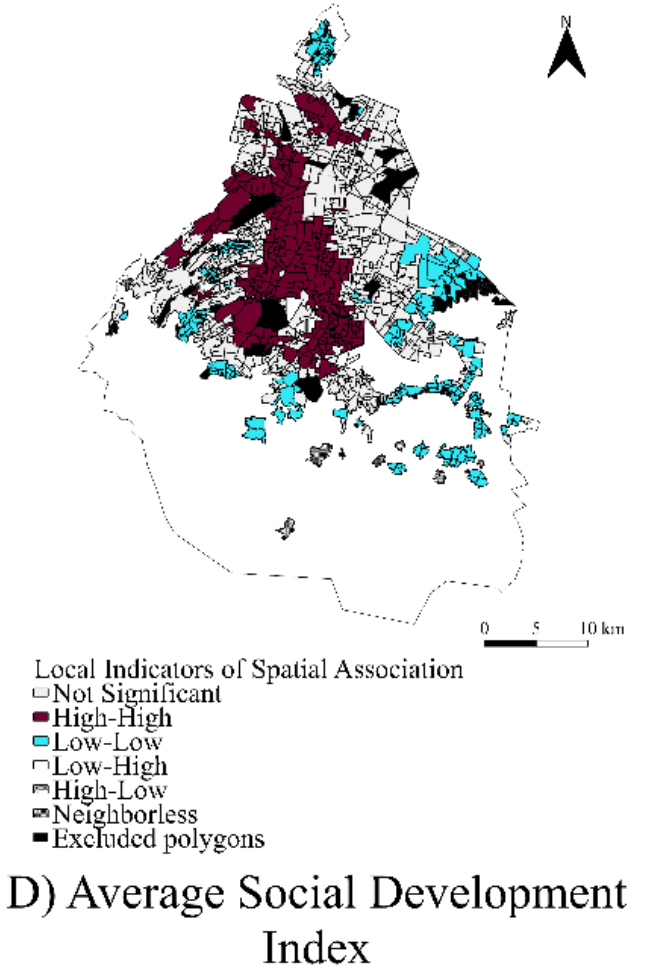

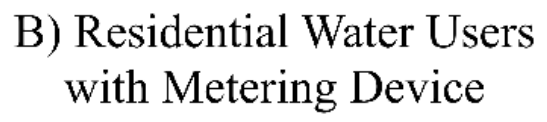
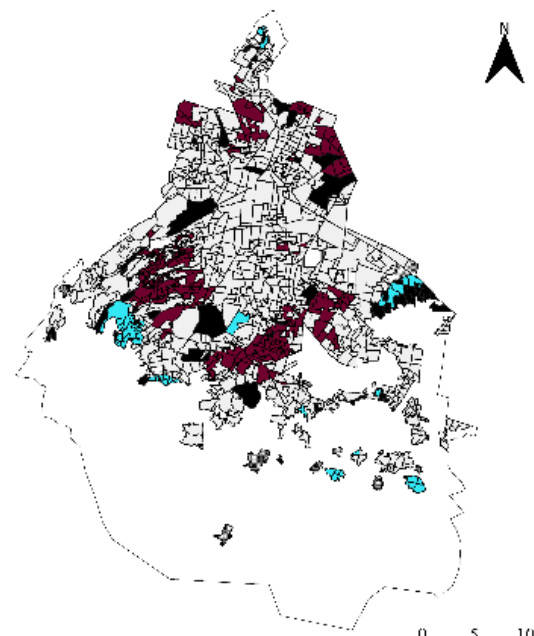

Local Indicators of Spatial Association

$\neg$ Not Significant

- High-High

-I OW-I.ow

-Low-High

Neighborless

- Excluded polygons

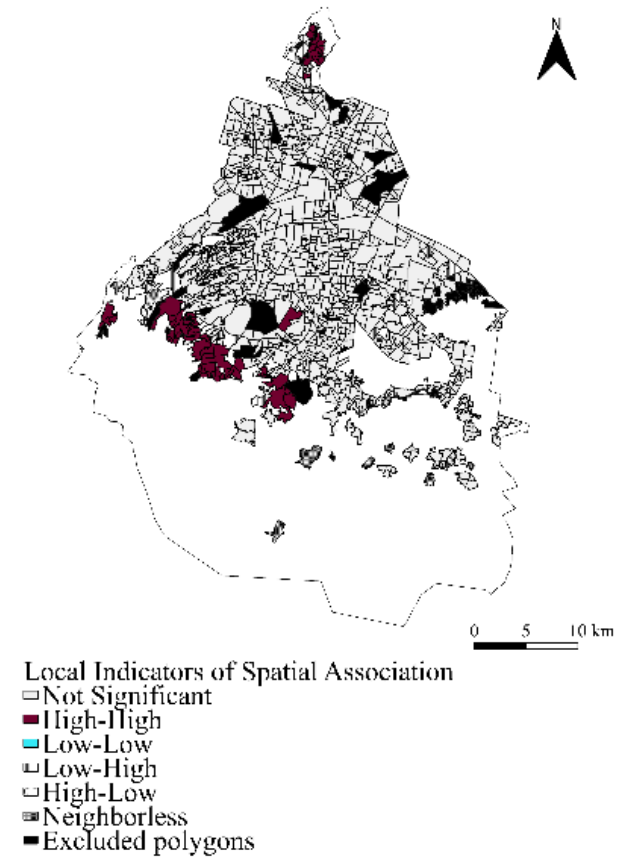

E) Intermittent Water

Supply

\section{C) Dwellings with Internal Water Connection}

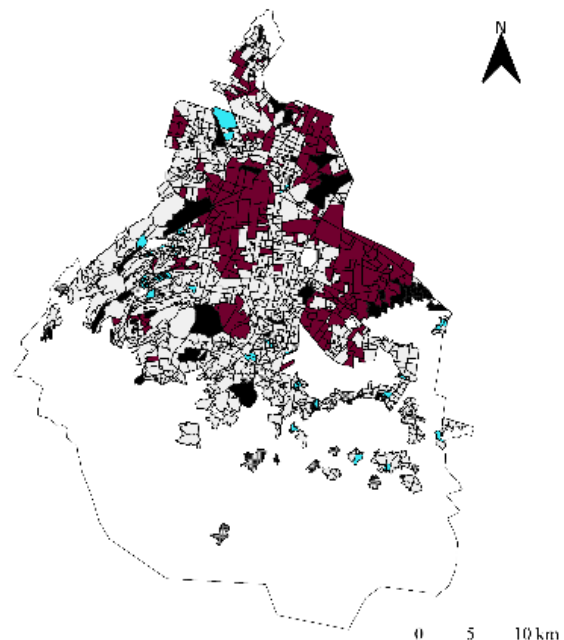

Local Indicators of Spatial Association

$\square$ Not Significant

- High-High

-Low-Low

-High-Low

Neighborless

- Excluded polygons

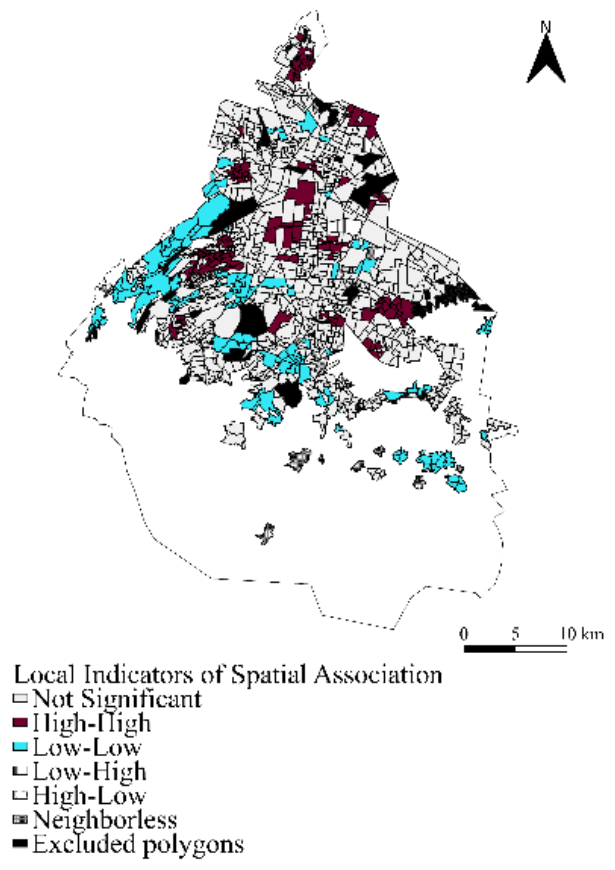

F) Dwelling

Density 


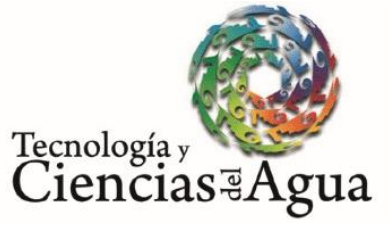

2021, Instituto Mexicano de Tecnología del Agua

Open Access bajo la licencia CC BY-NC-SA 4.0

(https://creativecommons.org/licenses/by-nc-sa/4.0/)

Figure 4. Local Indicators of Spatial Autocorrelation (LISA) for the dependent and independent variables for the analysis of annual residential water demand in Mexico City neighborhoods (clusters of high values are in dark red and clusters of low values are in light blue).

The Average Social Development Index and intermittent water supply exhibited the Moran's I highest values of 0.65 and 0.57 , respectively (Figures 4D and 4E). They were followed by the percentage of residential water users with a metering device (Figure 4B), which had an autocorrelation of 0.49 . The remaining three variables had Moran's I values around 0.34 and 0.37 , which are moderate but still statistically significant. Figures $4 \mathrm{~A}$ and $4 \mathrm{C}$ show similar spatially clustered patterns, but they both differ from Figure 4B, showing different spatial patterns among the location of dwellings, metering device coverage, and high levels of residential water demand.

Cluster of high values for the ID in Figure 4D are mainly located in the western side of the city, while low values appear in the southern and eastern sides. Some high residential water demand values from Figure 4A overlap with some others of the Social Development Index in Figure 4D. The case of intermittent water supply, shown in Figure $4 \mathrm{E}$, locates a spatial pattern of incidence mainly in the southwestern edge of the city, which corresponds to the mountain limits of the Basin of Mexico (Figure 1). Finally, dwelling density in Figure 4F shows a spatial cluster of low density in the western area and some neighborhoods in the southern part of the city. 


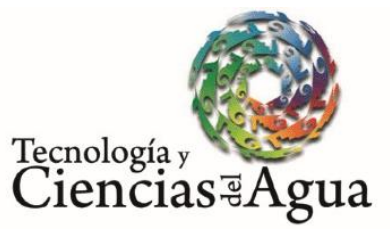

\section{Ordinary Least Squares Regression results}

Results of OLS multiple regression analysis are shown in Table 4 and correspond to Equation (1) from section "Independent variables selection". The five independent variables (remaining after the correlation matrix procedure): residential water users with metering device (control variable), dwellings with internal water connection, average Social Development Index, dwelling density, and intermittent water supply resulted statistically significant with the $95 \%$ confidence interval with the expected signs.

Table 4. Regression coefficients, standard errors, $t$-Statistics, and $p$ value of a log-log form Ordinary Least Squares multiple regression (OLS) model to estimate residential water demand in Mexico City neighborhoods (obtained from Equation (1)).

\begin{tabular}{|l|l|l|l|l|}
\hline \multicolumn{1}{|c|}{ Variable } & Coefficient & Standard error & t-Statistic & p-value \\
\hline Constant & 1.56 & 0.14 & 10.90 & 0.00 \\
\hline $\begin{array}{l}\text { Residential water users } \\
\text { with metering device } \\
(\%)\end{array}$ & 0.98 & 0.02 & 50.34 & 0.00 \\
\hline
\end{tabular}




\begin{tabular}{|c|c|c|c|c|}
\hline $\begin{array}{l}\text { Dwellings with internal } \\
\text { water connection (total } \\
\text { count) }\end{array}$ & 1.00 & 0.02 & 63.06 & 0.00 \\
\hline $\begin{array}{l}\text { Average } \\
\text { Development } \\
\text { (values from } 0 \text { to } 1 \text { ) }\end{array}$ & 1.99 & 0.14 & 13.99 & 0.00 \\
\hline Dwelling density (ha) & -0.11 & 0.02 & -4.64 & 0.00 \\
\hline $\begin{array}{ll}\text { Intermittent } & \text { water } \\
\text { supply (dummy) } & \end{array}$ & -0.37 & 0.06 & -6.20 & 0.00 \\
\hline$R^{2}$ & 0.87 & & & \\
\hline $\begin{array}{l}\mathrm{AIC} \\
n\end{array}$ & $\begin{array}{l}2338.67 \\
1346\end{array}$ & & & \\
\hline
\end{tabular}

The model explains $87 \%$ of annual residential water demand in Mexico City. The contribution of the independent control variable and dwellings with internal water connection is similar. An increase in $1 \%$ of these two variables would be reflected in approximately $1 \%$ of extra residential water demand. The Social Development Index has the highest coefficient of all variables, indicating an augmentation of $1 \%$ in this index would increase water demand by almost $2 \%$. Intermittent water supply has a negative sign, which is expected as it represents a restriction of access to water services. Dwelling density has a negative sign coefficient, which is the lowest. Residuals from the OLS multiple regression analysis had 0.27 Moran's I value, meaning they are spatially autocorrelated. 


\section{Geographically Weighted Regression results}

Results from GWR analysis stemming from Equation (2) of section "Independent variables selection" appear in Table 5. They show a little improvement over the $\mathrm{R}^{2}$ compared to the OLS, as it is $2 \%$ higher. In contrast, the AIC of the GWR analysis is smaller than the OLS, suggesting better adjustment. Signs and magnitudes form the coefficients vary according to their location, contrasting with results in Table 4.

Table 5. Geographically Weighted Regression (GWR) coefficients of a log-log form model to estimate residential water demand in Mexico City neighborhoods (obtained from Equation (2)).

\begin{tabular}{|l|l|l|l|l|}
\hline \multicolumn{1}{|c|}{ Variable Minimum } & \multicolumn{1}{|c|}{ Median } & Maximum & Range \\
\hline Intercept & 0.25 & 2.42 & 5.11 & 4.86 \\
\hline $\begin{array}{l}\text { Residential water users } \\
\text { with metering device (\%) }\end{array}$ & 0.05 & 0.85 & 1.18 & 1.13 \\
\hline $\begin{array}{l}\text { Dwellings with internal } \\
\text { water connection (total } \\
\text { count) }\end{array}$ & 0.91 & 0.98 & 1.07 & 0.15 \\
\hline $\begin{array}{l}\text { Average Index } \\
\text { Development } \\
\text { (values from 0 to 1) }\end{array}$ & 0.78 & 1.47 & 2.24 & 1.45 \\
\hline
\end{tabular}


Ciencias $₫$ Agua

\begin{tabular}{|l|l|l|l|l|} 
Dwelling density (ha) & -0.35 & -0.06 & 0.21 & 0.57 \\
\hline $\begin{array}{l}\text { Intermittent water supply } \\
\text { (dummy) }\end{array}$ & -5.49 & -0.32 & 0.22 & 5.71 \\
\hline$R^{2}$ & 0.89 & & \\
\cline { 1 - 3 } & 2091.96 & & \\
\cline { 1 - 3 } & 1346 & &
\end{tabular}

The extent of the control variable coefficients grows from 0.05 to 1.18, showing bigger variation than dwellings with internal water connection. Dwelling density and intermittent water supply exhibit most of their coefficients with negative signs. In contrast, some spatial units have positive signs, meaning that water demand would increase in terms of these two variables. Elasticities of the Social Development Index vary from 0.78 to 2.24; although this determinant has one of the highest values it is not the case for all spatial units. These are some relevant differences that contrast with the global stationary OLS analysis. Local coefficients of the study area are displayed in Figure 5. 
Tecnología y

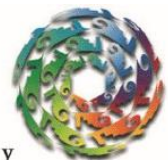

Ciencias $\stackrel{\Xi}{\Im}$ Agua

A) Residential Water Users with Metering Device

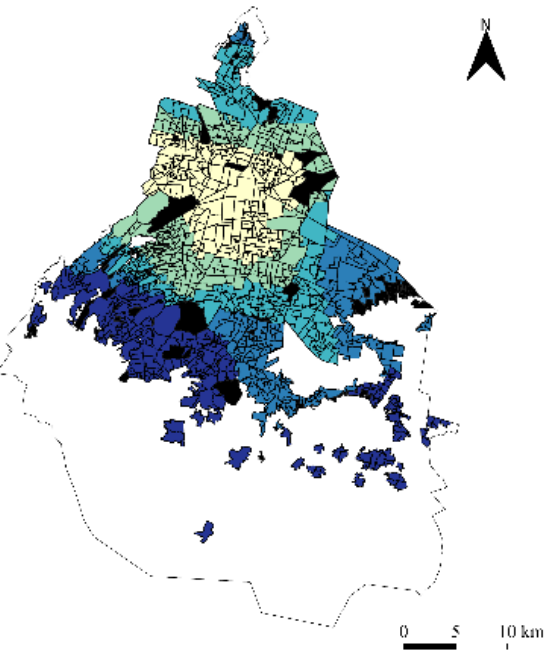

PC Local Coefficients

$\square 0.051-0.381$

$\square 0.381-0.696$

$=0.696-0.936$

$=0.936-1.001$

-Excluded polygons

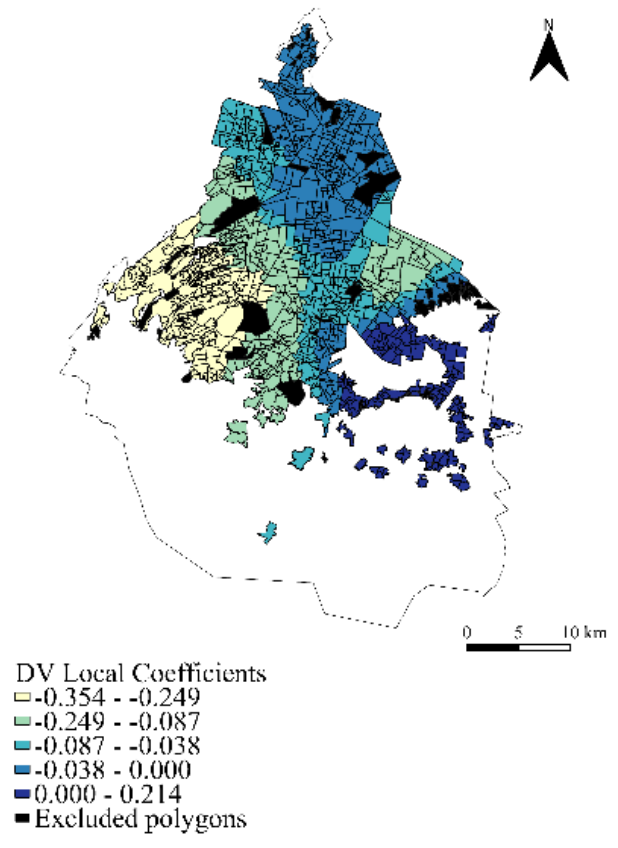

D) Dwelling denstiy
2021, Instituto Mexicano de Tecnología del Agua

Open Access bajo la licencia CC BY-NC-SA 4.0

(https://creativecommons.org/licenses/by-nc-sa/4.0/)
B) Dwellings with Internal Water Connection

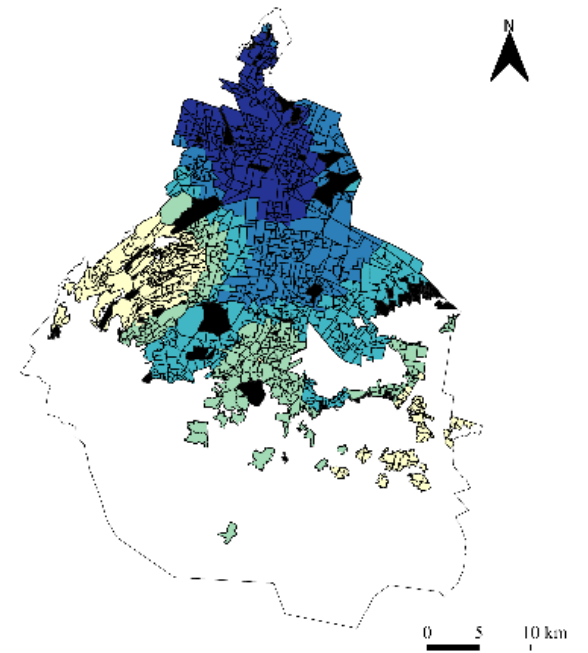

VA Local Coefficients

$\square 0.912-0.937$

$\square 0.937-0.967$

$=0.967-1.003$

$=1.003-1.027$

-Excluded polygons

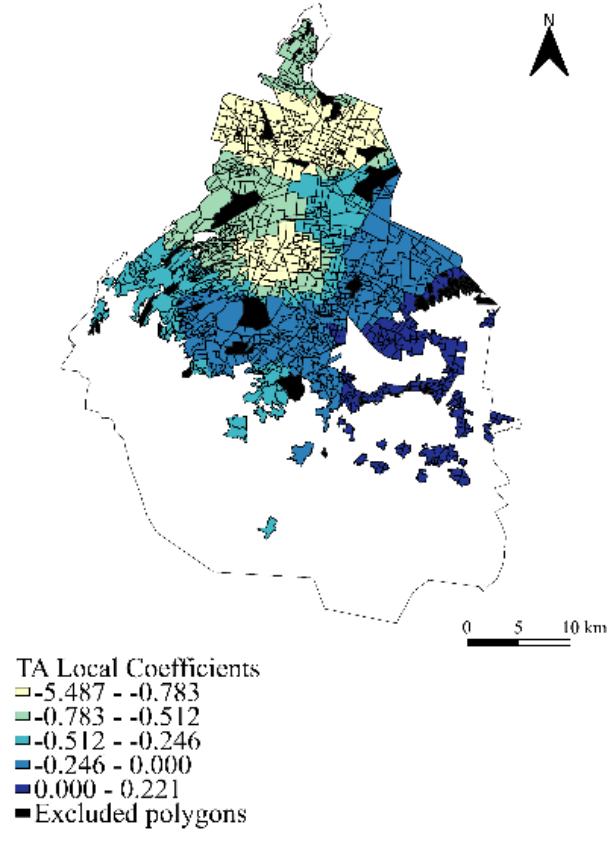

E) Intermittent Water Supply
C) Average Social

Development Index

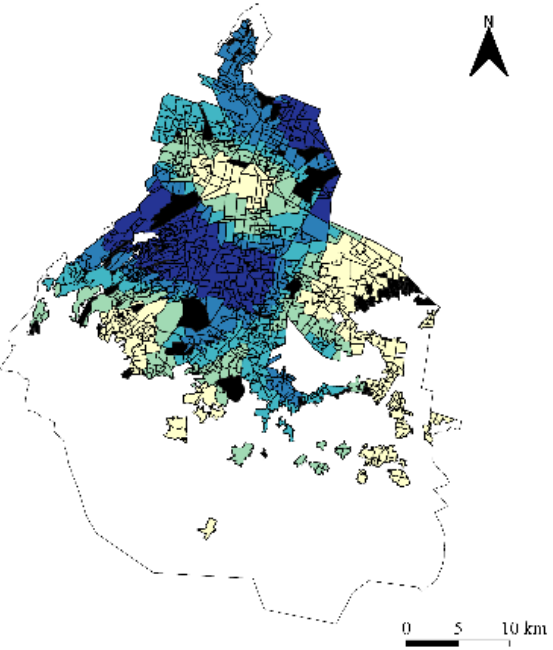

ID Local Cocfficicnts

$\neg 0.784-1.201$

$=1.201-1.416$
$=1.416-1.541$

$=1.541-1.730$

- Excluded polygons

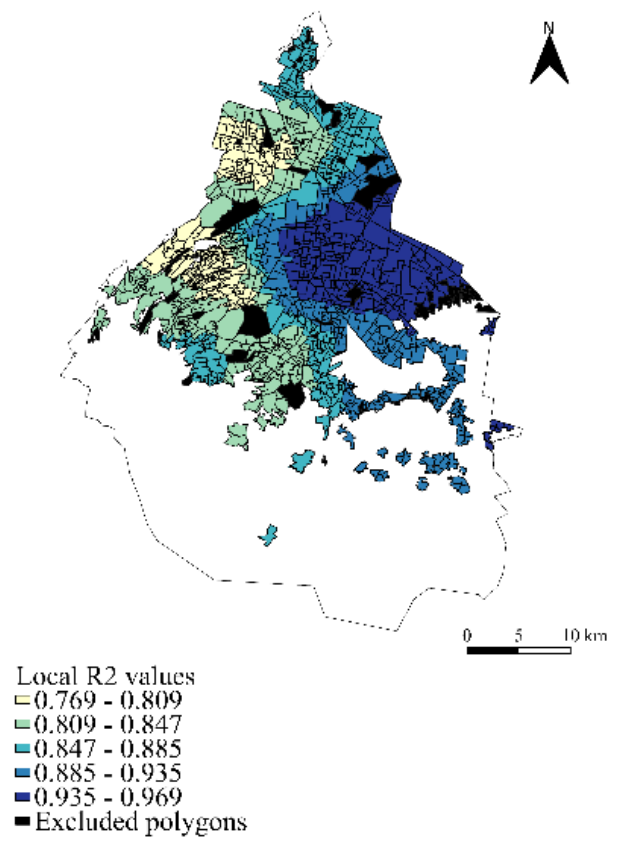

F) Local R2 Values 


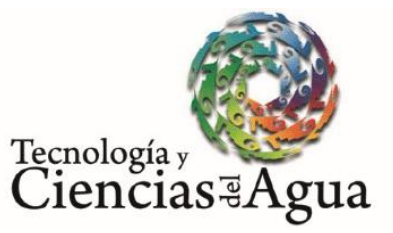

Figure 5. Quantile spatial distribution of local coefficients from the Geographically Weighted Regression (GWR) model to estimate residential water demand in Mexico City neighborhoods.

Figure 5A displays local coefficients of the control variable, where it can be observed low values in the central area while high values are located on the southwestern side; this means that water demand is less elastic to metering devices in central neighborhoods in contrast with the peripheral areas. The case of dwellings with internal water connection in Figure 5B shows a spatial pattern of high elasticity values in the north that diminishes southwards, although the lowest values are clustered in the western side; this determinant exhibits the lowest range of spatial variation (Table 5). The Social Development Index in Figure $5 \mathrm{C}$ shows high levels of elasticity with residential water demand in the centralwestern side of the city, while the lowest values are located in three separate clusters, one in the central area, and the other two in the eastern and western peripheries.

Dwelling density in Figure 5D shows some positive signs in the southeastern peripheral neighborhoods, meaning these determinants would increase residential water demand in these areas, although these coefficients are not high, a $10 \%$ increase would be translated into $2 \%$ of extra demand. The case of intermittent water supply is relevant to acknowledge, as it presents the highest spatial variation. Since this determinant represents a restriction to access to water services, the central and northern areas would be more affected in case those neighborhoods had this type of water supply, which would create a 


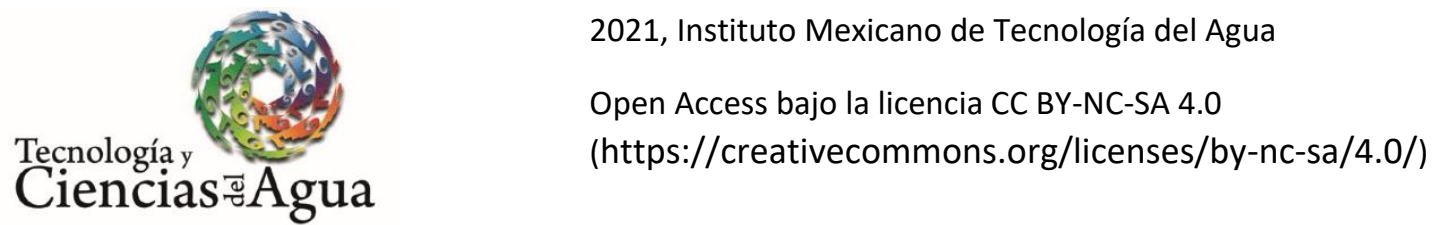

substantial reduction of residential water demand in the neighborhoods having the highest values of the dependent variable.

The characteristics of the spatial clusters from Figure 5 appear in Table 6. Local values for residential water demand, average percent of residential water users with metering device, total number of dwellings with internal water connection, average household size, average Social Development Index, average dwelling density and the total number of neighborhoods with intermittent water supply were assembled in terms of the elasticities calculated by the GWR analysis.

Table 6. Characteristics of spatial clusters in terms of quantile elasticities distribution. Spatial clusters: Residential users with metering device (PC), total dwellings with internal water connection (VA), average Social Development Index (ID), dwelling density (DV) and intermittent water supply (TA).

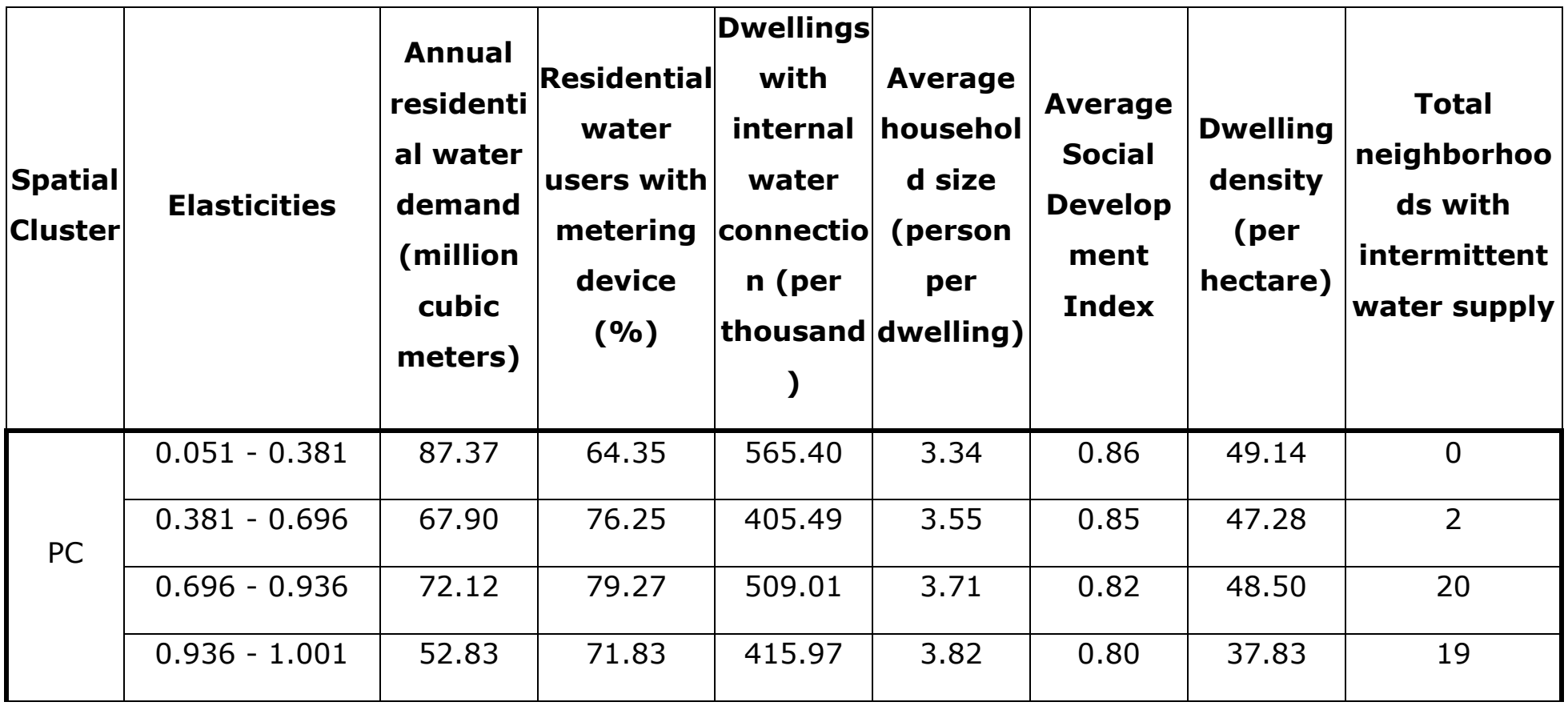




\begin{tabular}{|c|c|c|c|c|c|c|c|c|}
\hline & $1.001-1.178$ & 33.12 & 58.61 & 275.08 & 3.86 & 0.76 & 29.22 & 87 \\
\hline \multirow{5}{*}{ VA } & $0.912-0.937$ & 34.46 & 73.21 & 233.43 & 3.92 & 0.76 & 43.27 & 20 \\
\hline & $0.937-0.967$ & 46.93 & 68.38 & 298.44 & 3.61 & 0.83 & 31.80 & 44 \\
\hline & $0.967-1.003$ & 71.95 & 68.74 & 537.49 & 3.69 & 0.81 & 42.18 & 40 \\
\hline & $1.003-1.027$ & 85.95 & 70.88 & 579.09 & 3.53 & 0.85 & 48.92 & 6 \\
\hline & $1.027-1.067$ & 74.03 & 69.06 & 522.50 & 3.52 & 0.84 & 45.81 & 18 \\
\hline \multirow{5}{*}{ ID } & $0.784-1.201$ & 60.16 & 58.87 & 517.49 & 3.87 & 0.75 & 37.58 & 55 \\
\hline & $1.201-1.416$ & 59.77 & 65.62 & 415.20 & 3.60 & 0.82 & 42.81 & 39 \\
\hline & $1.416-1.541$ & 56.12 & 74.97 & 367.50 & 3.62 & 0.84 & 38.33 & 7 \\
\hline & $1.541-1.730$ & 60.34 & 75.45 & 422.16 & 3.68 & 0.83 & 42.94 & 26 \\
\hline & $1.730-2.237$ & 76.94 & 75.42 & 448.60 & 3.49 & 0.85 & 50.34 & 1 \\
\hline \multirow{5}{*}{ DV } & $-0.354--0.249$ & 43.77 & 71.26 & 281.34 & 3.77 & 0.80 & 43.54 & 60 \\
\hline & $-0.249--0.087$ & 75.01 & 71.21 & 501.41 & 3.49 & 0.85 & 43.11 & 31 \\
\hline & $-0.087--0.038$ & 70.71 & 74.56 & 461.16 & 3.51 & 0.86 & 44.32 & 5 \\
\hline & $-0.038-0$ & 106.51 & 69.56 & 765.01 & 3.58 & 0.83 & 46.77 & 24 \\
\hline & $0-0.214$ & 17.32 & 60.64 & 162.03 & 4.08 & 0.71 & 27.72 & 8 \\
\hline \multirow{5}{*}{ TA } & $-5.487--0.783$ & 79.07 & 71.11 & 519.95 & 3.38 & 0.87 & 45.14 & 0 \\
\hline & $-0.783--0.512$ & 73.52 & 72.27 & 449.33 & 3.52 & 0.83 & 53.41 & 22 \\
\hline & $-0.512--0.246$ & 48.34 & 66.49 & 355.85 & 3.77 & 0.80 & 41.50 & 49 \\
\hline & $-0.246-0$ & 91.03 & 76.16 & 635.90 & 3.66 & 0.84 & 39.59 & 49 \\
\hline & $0-0.221$ & 21.36 & 59.38 & 209.91 & 4.04 & 0.72 & 29.47 & 8 \\
\hline \multicolumn{2}{|c|}{ Mexico City } & 313.33 & 70.06 & 2170.95 & 3.65 & 0.82 & 42.40 & 128 \\
\hline
\end{tabular}




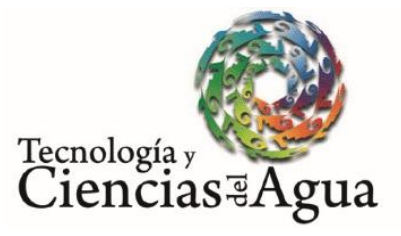

2021, Instituto Mexicano de Tecnología del Agua

Open Access bajo la licencia CC BY-NC-SA 4.0

(https://creativecommons.org/licenses/by-nc-sa/4.0/)

High residential water demand clusters are characterized by the highest number of dwellings with internal water connection, small average household size, high average Social Development Index, and high dwelling density. These areas are also characterized by a low number of neighborhoods with intermittent water supply. According to Table 6, high coverage of metering devices does not necessarily show the highest levels of residential water demand.

\section{Residential water demand prediction and estimation}

Figure 6 shows the predicted values of residential water demand stemming from both models. These results are compared to observed data from Sacmex; in both cases an underestimation is present. Two estimations of residential water demand in Mexico City are presented based on coefficients from OLS and GWR analyses. Estimations yielded a result of $13.70 \mathrm{~m}^{3} / \mathrm{s}$ with OLS coefficients and $15.33 \mathrm{~m}^{3} / \mathrm{s}$ with GWR coefficients. 

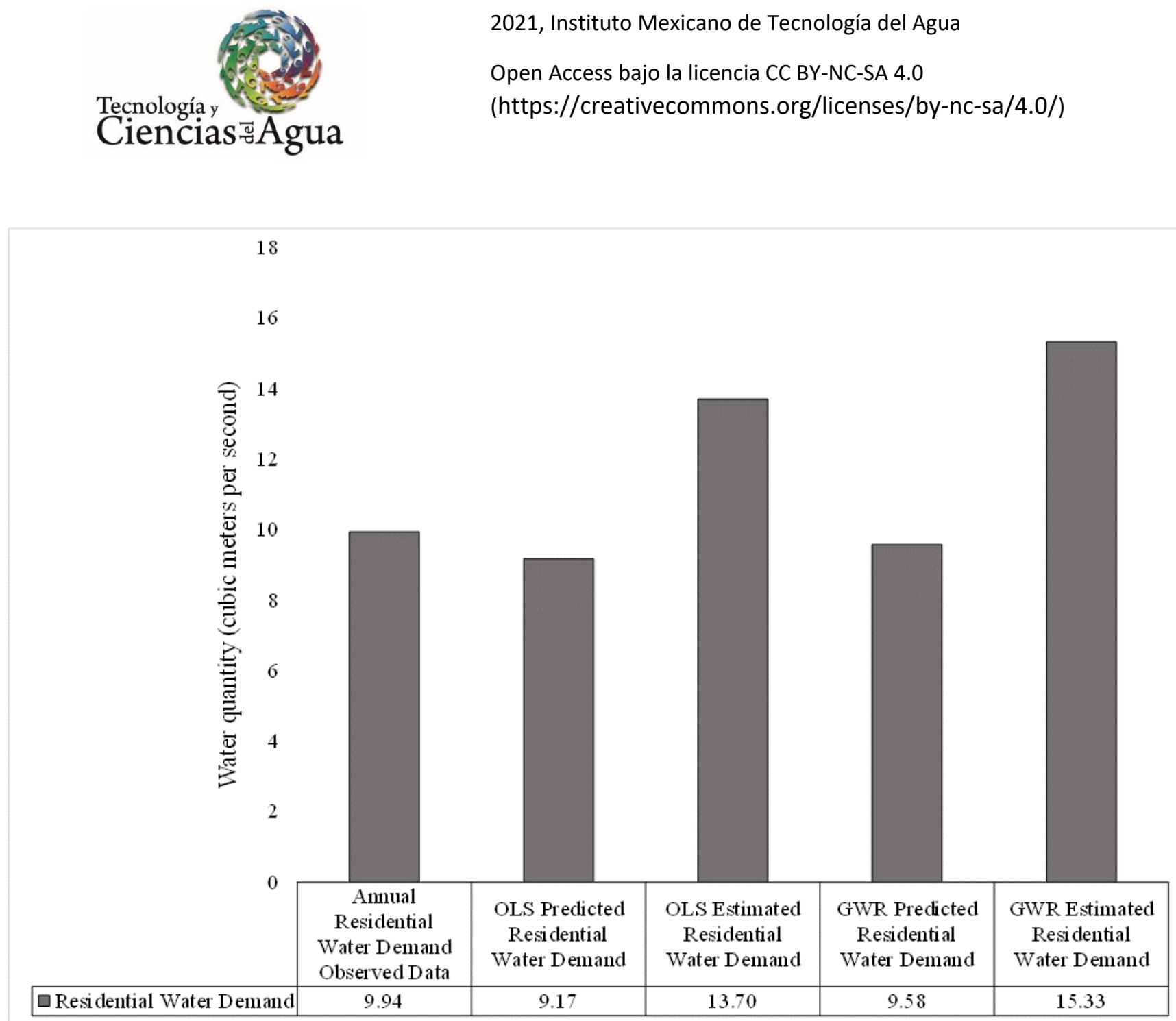

Figure 6. Observed, predicted, and estimated annual residential water demand with OLS and GWR models in Mexico City, 2010 (Estimated residential water demand columns already include unaccounted residential water quantity).

Residential water demand estimation from the OLS model represents $43.43 \%$ of total supply to Mexico City $\left(31.54 \mathrm{~m}^{3} / \mathrm{s}\right)$ while the GWR estimation accounts for $48.59 \%$. These results highlight the need to address unaccounted water quantity as well as water losses in comparison to water supply, to create a demand-side view of water 


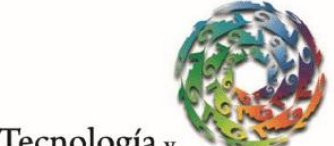 \\ Ciencias $₫$ Agua}

2021, Instituto Mexicano de Tecnología del Agua

Open Access bajo la licencia CC BY-NC-SA 4.0

(https://creativecommons.org/licenses/by-nc-sa/4.0/)

management encompassing IUWM principals to impact on the water supply component.

\section{Discussion}

Mexico City's central area is the top priority for residential water demand reduction. It is characterized by a cluster of neighborhoods with high values of residential water demand with low levels of metering coverage. These values are also related to high numbers of residential dwellings with internal water connection, irrespective of their metering coverage. This point is similar to the findings of Tanverakul and Lee (2015) and Ojeda et al. (2017), where places without measurement tended to use more water in comparison to areas with good metering coverage. Peripheral areas, although showing high elasticities for residential water demand in terms

of metering coverage, also show high levels of intermittent water supply which represent a restriction of access to water services. This point highlights differences in water demand in the center and the edges of the city, although both account for a similar level of metering water coverage. Management actions must take this point into consideration.

Residential water demand in Mexico City is linked to public services provision. High levels of residential water demand are associated with high levels of the Social Development Index, small household size, and 


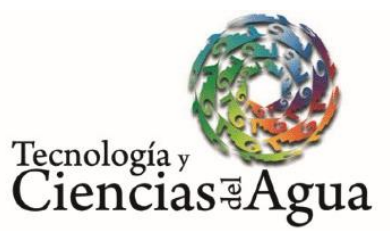

low incidence of intermittent water supply. Similar results were reported by Montesillo (2004), and Dávila and Constantino (2007), where similar socioeconomic variables were correlated to water use, while Jiménez et al. (2011) mentioned poverty levels were related to defficient access to water services. Following the spatial clusters of the index, a centralwestern pattern of neighborhoods with high values is found which might be related to the urban development pattern of the city, as eastern neighborhoods are the result of consolidated slums that emerged without urban planning. As small household size appears in neighborhoods with high residential water demand, a study of water use intensity is warranted.

Dwelling density effects on residential water demand must be taken in a broader context. Although the global OLS analysis shows dwelling density with a negative sign, similar to Chang et al. (2010), Shandas and Parandvash (2010), Ghavidelfar and Shamseldin (2017), and Stoker et al. (2019), some negihborhoods exhibit positive coefficients as a result of the GWR analysis (Fotheringham et al., 2002). These coefficients are located in the southeastern side, the rural area of the city, where densification would create extra water demand. High density areas are also those having high levels of residential water demand and Social Development Index. Although dwelling density might have the potential to reduce water demand other variables have stronger effects.

Intermittent water supply plays an important role in explaining residential water demand. Since deficient access to water services is a relevant concern in Mexico City, calculated local coefficients show that central and northern neighborhoods would be more affected when facing this type of supply. Neighborhoods in the southeastern side present positive coefficients to this variable, which coincide with the location of 


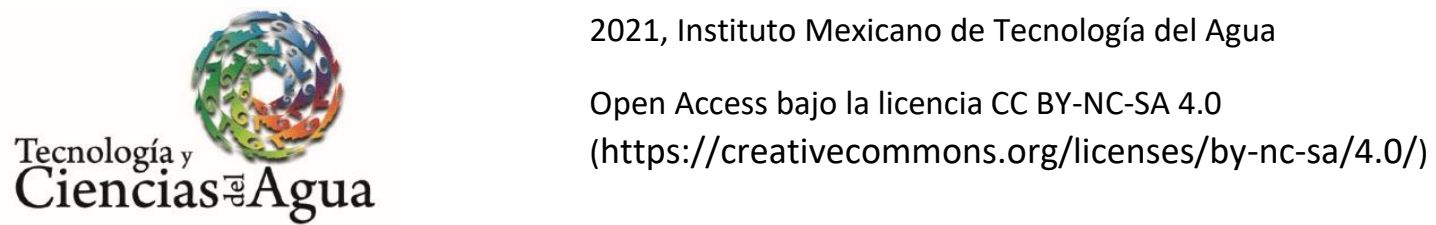

the Southern system of water supply. In turn, the Northern and Central systems provide around $10 \%$ of total water supply, where the highest coefficients of intermittent water supply are located. This result suggests a high dependence of the central and northern areas on exterior sources, but it also suggests their vulnerability to intermittent water supply in case of happening, despite these areas are also characterized by high levels of infrastructure. Therefore, the water deficit mentioned by Morales and Rodríguez (2009) and the low water availability statement from the local water management programs (GDF, 2007; GDF, 2012), are not a mere question of quantity. It is still needed to understand the cause of intermittent water supply reported in the local government official newspaper, as well as to explore the effects of hourly supply frequency and water quality issues on residential water demand.

As IUWM states the need to address water demand in a multifaceted way (Mitchell, 2006) and also to look for the best options to balance water supply and demand (Baumann \& Boland, 1998), the case of Mexico City should focus on the spatial distribution of socioeconomic characteristics, dwelling density and access to water services instead of just population growth. This is one turning point to conceive water management from a demand-side view. 


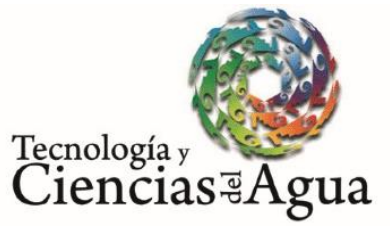

\section{Conclusions}

In this study a diagnosis and two estimations of residential water demand in Mexico City were exposed, based on a OLS multiple regresion and a GWR models. Socioeconomic and access to water services variables resulted the most important determinants of residential water demand rather than urban density, highlighting the IUWM principal of water demand being more than a question of quantity; these type of analyses are useful to impact in urban water supply management, as well as on the evaluation of different sources. Central neighborhoods are the priority area to implement water demand reduction. The exploratory estimations of residential water demand for the whole city offer an insight on the need to address water losses. Resultant coefficients are helpful to advice public policymakers on decisions related to water management, to face the current water challenges of Mexico City.

More research is still needed on access to water services and its relation with residential water demand since variables such as hourly water frequency provision and drinking water quality would give more insights. Balance of water demand and supply must be approached from a spatial view, as provision areas are not the sites where water is consumed. Residential water use intensity must be studied as neighborhoods with small household sizes are also those consuming high volumes of water. Another relevant issue to examine is the role of water losses in explaining water demand. These points constitute a complement 


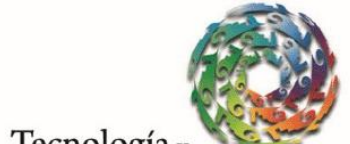 \\ Tecnología y \\ Ciencias $\approx$ Agua}

2021, Instituto Mexicano de Tecnología del Agua

Open Access bajo la licencia CC BY-NC-SA 4.0

(https://creativecommons.org/licenses/by-nc-sa/4.0/)

to the results obtained from this study to encompass a water demandside view from IUWM for Mexico City.

\section{Acknowledgments}

We appreciate Dr. Manuel Suárez Lastra and Dr. Leticia Gómez Mendoza for their help on improving the ideas of this study. Thanks to Karla Beatrice Andrade for her help on style revision; and to the trasnparency office personell of Sacmex for their kind help on retrieving data used in this research.

\section{References}

Agthe, D., \& Billings, R. (2003). Elasticity of demand for water resource managers. In: Agthe, D., Billings, R., \& Buras, N. (eds.). Managing urban water supply (pp. 71-86). Baton Rouge, USA: Kluwer Academic.

ALDF, Asamblea Legislativa del Distrito Federal. (2003). Ley de Aguas del Distrito Federal. México, DF, México: Gobierno del Distrito Federal.

Anselin, L. (2005). Exploring Spatial Data with GeoDa: A Workbook. Santa Barbara, USA: Center for Spatially Integrated Social Science.

Arbués, F., \& Villanúa, I. (2006). Potential for pricing policies in water resources management: Estimation of urban residential water demand in Zaragoza, Spain. Urban Studies, 43(13), 2421-2442.

Arbués, F., García-Valiñas, M., \& Martínez-Espiñeira, R. (2003). Estimation of residential water demand: A state-of-the-art review. Journal of Socio-Economics, 32, 81-102. 


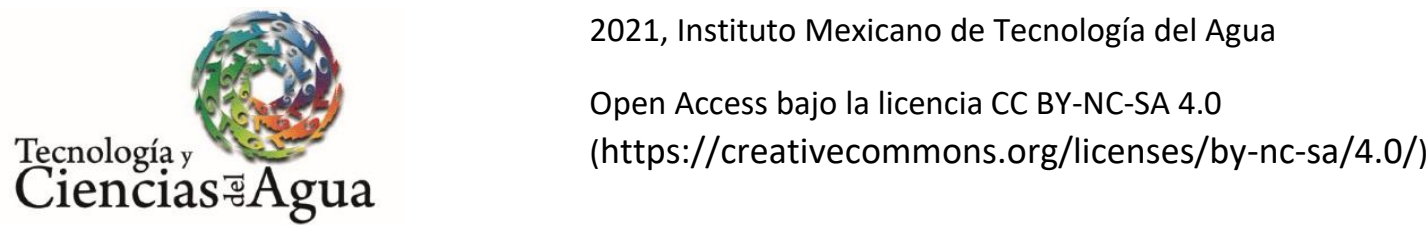

Ashoori, N., Dzombak, D., \& Small, M. (2016). Modeling the effects of conservation, demographics, price, and climate on urban water demand in Los Angeles, California. Water Resources Management, 30, 5247-5262.

Babel, M., Das Gupta, A., \& Pradhan, P. (2007). A multivariate econometric approach for domestic water demand modeling: An application to Kathmandu, Nepal. Water Resource Management, 21, 573-589.

Bahri, A. (2011). Hacia la gestión integrada de aguas urbanas. Estocolmo, Suecia: Global Water Partnership.

Baumann, D., \& Boland, J. (1998). The case for managing urban water. In: Baumann, D., Boland, J., \& Hanemann, W. Urban water demand management and planning (pp. 1-30). New York, USA: McGraw Hill.

Billings, R., \& Jones, C. (2008). Forecasting urban water demand ( $\left.2^{\text {nd }} e d.\right)$. Denver, USA: American Water Works Association.

Burt, J., Barber, G., \& Rigby, D. (2009). Elementary statistics for geographers ( $3^{\text {rd }}$ ed.). New York, USA: Guilford.

Buzai, G., \& Baxendale, C. (2012). Análisis socioespacial con sistemas de información geográfica. Ordenamiento territorial. Temáticas de base vactorial. Buenos Aires, Argentina: Lugar Editorial.

Chang, H. (2017). Water conservation. In: Richardson, D. (ed.). The international encyclopedia of geography: People, the earth, environment, and technology (pp. 7623-7628). Chichester, West Sussex, UK: Wiley Blackwell. 


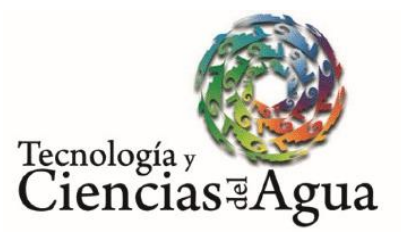

2021, Instituto Mexicano de Tecnología del Agua

Open Access bajo la licencia CC BY-NC-SA 4.0

(https://creativecommons.org/licenses/by-nc-sa/4.0/)

Chang, H., Bonnette, M., Stoker, P., Crow-Miller, B., \& Wentz, E. (2017). Determinants of single family residential water uses across scales in four western US cities. Science of the Total Environment, 596/597, 451-464.

Chang, H., Hossein, G., \& Shandas, V. (2010). Spatial variation of singlefamily residential water consumption in Portland, Oregon. Urban Geography, 31(7), 953-972.

Conagua, Comisión Nacional del Agua. (2009). Ley de Aguas Nacionales y su Reglamento. México, DF, México: Secretaría de Medio Ambiente y Recursos Naturales.

Conagua, Comisión Nacional del Agua. (2018). Estadísticas del agua en México. Ciudad de México, México: Secretaría de Medio Ambiente y Recursos Naturales.

Dávila, H., \& Constantino, R. (2007). Sistema de uso de derechos de agua potable en el Distrito Federal. En: Economía del agua. Escasez del agua y su demanda doméstica e industrial en áreas urbanas (pp. 149-179). México, DF, México: Cámara de Diputados, Porrúa, Universidad Autónoma Metropolitana.

De-Maria-André, D., \& Carvalho, J. (2014). Spatial determiants of urban residential water demand in Fortaleza, Brazil. Water Resources Management, 28, 2401-2414.

Domene, E., \& Saurí, D. (2006). Urbanisation and water consumption: Influencing factors in the metropolitan region of Barcelona. Urban Studies, 43, 1605-1623. 


\section{Tecnología y}

Downs, T., Mazari-Hiriart, M., Domínguez-Mora, R., \& Suffet, I. (2000). Sustainability of least cost policies for meeting Mexico City's future water demand. Water Resources Research, 36(8), 2321-2339.

Escolero, O., Kraslisch, S., Martínez, S., \& Perevochtchikova, M. (2016). Diagnóstico y análisis de los factores en la vulnerbilidad de las fuentes de abastecimiento de agua potable a la Ciudad de México, México. Boletín de la Sociedad Geográfica Mexicana, 68(3), 409427.

Evalúa CDMX, Consejo de Evaluación del Desarrollo Social del Distrito Federal. (March 11, 2016). Índice de desarrollo social de las unidades territoriales del Distrito Federal/IEDS (DelegacionesColonias-Manzanas). Recovered from http://www.evalua.cdmx.gob.mx/medicion-unidades-territoriales2010.php

Fotheringham, A., Brunsdon, C., \& Charlton, M. (2002). Geographically weighted regression: The analysis of spatially varying relationships. New York, USA: Wiley.

GDF, Gobierno del Distrito Federal. (2007). Programa de manejo sustentable del agua para la Ciudad de México. Ciudad de México, México: Secretaría del Medio Ambiente, Secretaría de Obras y Servicios, Sistema de Aguas de la Ciudad de México.

GDF, Gobierno del Distrito Federal. (May 13, 2010). Administración Pública del Distrito Federal. Secretaría de Finanzas. Gaceta Oficial del Distrito Federal, pp. 4-9.

GDF, Gobierno del Distrito Federal. (2012). Programa de Gestión Integral de los Recursos Hídricos, Visión 20 Años. Ciudad de México, México: 


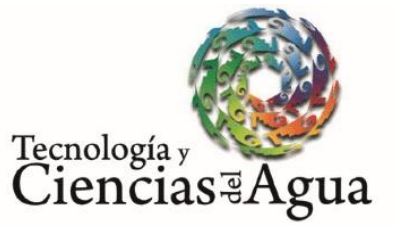

2021, Instituto Mexicano de Tecnología del Agua

Open Access bajo la licencia CC BY-NC-SA 4.0

(https://creativecommons.org/licenses/by-nc-sa/4.0/)

Secretaría del Medio Ambiente, Sistemas de Agua de la Ciudad de México.

Ghavidelfar, S., \& Shamseldin, A. (2017). A multi-scale analysis of singleunit housing water demand through integration of water consumption, land use and demographic data. Water Resources Management, 31, 2173-2186.

House-Peters, L., \& Chang, H. (2011). Urban water demand modeling: Review of concepts, method and organizing principales. Urban Water Research, 47, W05401. DOI: 10.1029/2010WR009624.

House-Peters, L., Pratt, B., \& Chang, H. (2010). Effects of urban spatial structure, sociodemographics and climate on residential water consumption in Hillsboro, Oregon. Journal of the American Water Resources Association, 46(3), 461-472.

INEGI, Instituto Nacional de Estadística y Geografía. (2012). Censo de Población y Vivienda 2010. Sistema para la Consulta de Información Censal (SCINCE Versión 05/12). Recovered from http://www.inegi.org.mx/est/scince/scince2010.aspx

Jiménez, B., Gutiérrez, R., Marañón, B., \& González, A. (2011). Evaluación de la política de acceso al agua potable en el Distrito Federal. México, DF, México: Evalúa DF, Programa Universitario de Estudios sobre la Ciudad, Universidad Nacional Autónoma de México.

Kontokosta, C., \& Jain, R. (2015). Modeling the determinants of largescale building water use: Implications for data-driven urban sustability policy. Sustainable Cities and Society, 18, 44-55. 


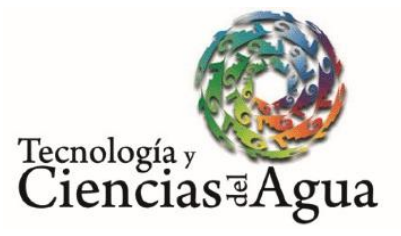

March, H., \& Saurí, D. (2009). What lies behind domestic water use? A review essay on the drivers of domestic water consumption. Boletín de la $A G E, 50,297-314$.

Martínez, M. (2004). La participación de la empresa privada en la gestión de servicios de agua en el Distrito Federal. En: Libreros, H., López, R., Martínez, M., Montesillos, J., Ortiz, G., \& Quiñones, A. (eds.). Gestión del agua en el Distrito Federal. Retos y propuestas (pp. 1557). México, DF, México: Programa Universitario de Estudios sobre la Ciudad, Universidad Nacional Autónoma de México.

Martínez, S., Escolero, O., \& Perevochtchikova, M. (2015). A comprehensive approach for the assessment of shared aquifers: The case of Mexico City. Sustainable Water Resources Management, $1(2), 111-123$.

Mayer, P. W., De-Oreo, W. B., Opitz, E., Keifer, J., Dziegielewski, B., Davis, W., \& Nelson, J. O. (1999). Residential end uses of water. Denver, USA: American Water Works Association.

Mitchell, G. (2006). Applying integrated urban water management concepts: A review of Australian experience. Environmental Management, 37(5), 589-605.

Montesillo, J. (2004). Estructura tarifaria. Análisis económico de la estructura tarifaria del servicio de agua potable en el Distrito Federal. En: Gestión del agua en el Distrito Federal. Retos y propuestas (pp. 101-149). México, DF: Programa Universitario de Estudios sobre la Ciudad, Universidad Nacional Autónoma de México.

Morales, J., \& Rodríguez, L. (2009). Política hídrica en la Zona Metropolitana del Valle de México y riesgos para suminisrar agua al 


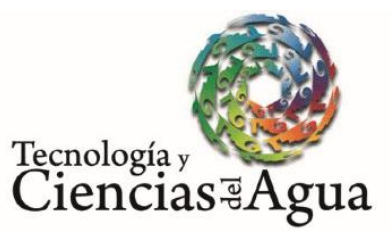

uso doméstico e industrial. En: Montero, D., Gómez, E., Carrillo, G., \& Rodríguez, L. (eds.). Innovación tecnológica, cultura y gestión del agua. Nuevos retos del agua en el Valle de México (pp. 21-53). México, DF, México: Porrúa, Universidad Autónoma Metropolitana, Cámara de Diputados.

Ojeda, A., Álvarez, C., Ramos, M., \& Soto, F. (2017). Determinants of domestic water consumption in Hermosillo, Sonora, Mexico. Journal of Cleaner Production, 142, 1901-1910.

Perevochtchikova, M. (2015). Agua y ciudad: el abasto de agua potable en la Ciudad de México. En: Schteingart, M., \& Piréz, P. (eds.). Dos grandes metrópolis latinoamericanas: Ciudad de México y Buenos Aires. Una perspectiva comparativa (pp. 239-260). Ciudad de México, México: El Colegio de México.

Perló, M., \& González, A. (2009). ¿Guerra por el agua en el Valle de México? Estudio sobre las relaciones hidráulicas entre el Distrito Fderal y el Estado de México (2a ed.). México, DF, México: Programa Universitario de Estudios sobre la Ciudad, Universidad Nacional Autónoma de México.

Pinkham, R. (1999). 21st century water systems: Scenarios, visions, and drivers. Recovered from http://www.rmi.org/KnowledgeCenter/Library/W99-21_21stCenturyWater

Ramos-Bueno, A. (2016). Análisis socio-espacial de la demanda por uso doméstico de agua en la Ciudad de México (tesis de Maestría en Geografía). Ciudad de México, México: Universidad Nacional Autónoma de México.

Tecnología y ciencias del agua, ISSN 2007-2422, 12(2), 59-110. DOI: 10.24850/j-tyca-2021-02-02 


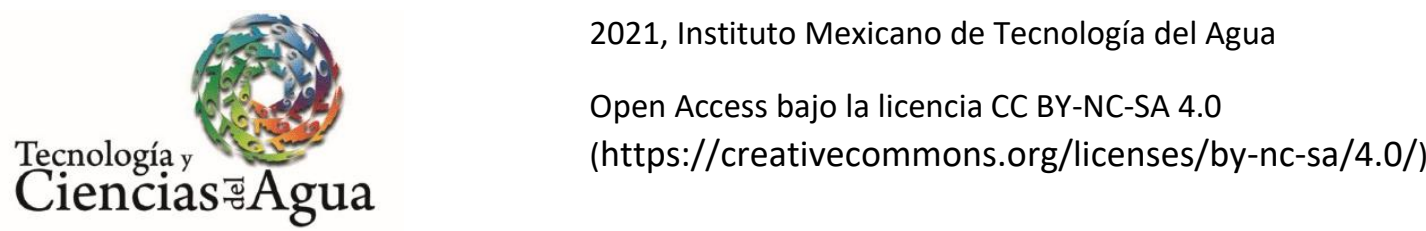

Sacmex, Sistema de Aguas de la Ciudad de México. (2014a). Portal de transparencia, solicitud de información pública 0324000022614. Consumo anual de agua, total de tomas instaladas para uso doméstico, total de tomas instaladas con medidor y nombre de colonias para el periodo 2008-2013. Recovered from https://infomexdf.org.mx/InfomexDF/consulta.html

Sacmex, Sistema de Aguas de la Ciudad de México. (2014b). Portal de transparencia, solicitud de información pública 0324000105214. Volumen total de agua suministrado a la Ciudad de México, 20082013. Recovered from https://infomexdf.org.mx/InfomexDF/consulta.html

Sacmex, Sistema de Aguas de la Ciudad de México. (2016). Portal de transparencia, solicitud de información pública 0324000111816. Volumen de agua extraído por pozos operados por el Sacmex con desglose mensual 2003-2015. Recovered from https://infomexdf.org.mx/InfomexDF/consulta.html

Sacmex, Sistema de Aguas de la Ciudad de México. (2019). Librería Virtual. Diagnósticos, logros y desafíos Sacmex 2018. Recovered from

http://data.sacmex.cdmx.gob.mx/aplicaciones/libreria/biblioteca/li bros/2018/diagnostico-logros-y-desafios-2018.pdf

Sánchez, A., Boltvinik, J., Ruiz, F., \& Figueroa, H. (2011). Índice de desarrollo social de las unidades territoriales del Distritio Federal. Delegación, colonia y manzana. México, DF, México: Evalúa DF, Consejo de Evaluación del Desarrollo Social del Distrito Federal. 


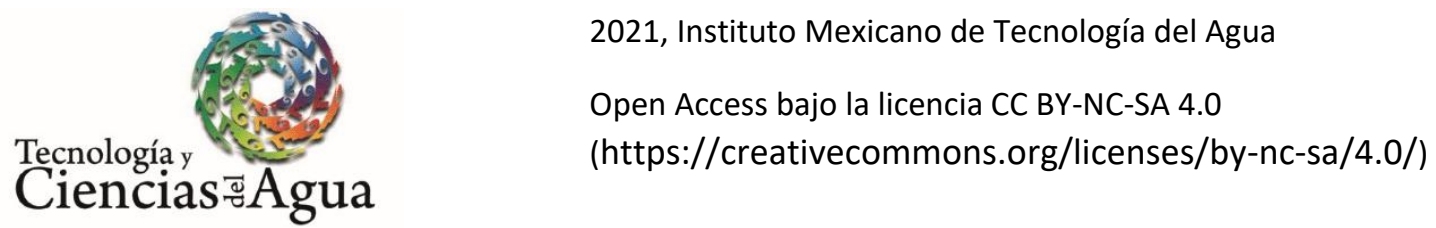

Saurí, D. (2013). Water conservation: Theory and evidence in urban areas of the developed world. Annual Review of Environment and Resources, 38, 227-248.

Seduvi, Secretaría de Desarrollo Urbano y Vivienda. (15 de abril, 2015). Portal de transparencia, solicitud de información pública 0105000279114. Colonias de la Ciudad de México. Recovered from http://devliferay.inai.org.mx:8080/web/guest/inicio

Shandas, V., \& Parandvash, G. (2010). Integrating urban form and demographics in water-demand management: An empirical case study of Portland, Oregon. Environment and Planning B: Planning and Desing, 37, 112-128.

Stoker, P., Chang, H., Wentz, G., Crow-Miller, B., Jehle, G., \& Bonnette, M. (2019). Building water-efficient cities. Journal of the American Planning Association, 85(4), 511-524.

Tanverakul, S., \& Lee, J. (2015). Impacts of metering on residential water use in California. Journal of American Water Works Association, 107(2), E69-E75.

Tiburcio, A., \& Perevochtchikova, M. (2012). Indicadores ambientales en la gestión del agua urbana. En: Perevochtchikova, M. (ed.). Cultura del agua en México. Conceptualización y vulnerabilidad social (pp. 377-399) México, DF, México: Universidad Nacional Autónoma de México, Porrúa.

Turner, V., \& Ibes, D. (2011). The impact of homeowners associations on residential water demand management in Phoenix, Arizona. Urban Geography, 32(8), 1167-1188. 
UN, United Nations. (May 16, 2018). Department of Economic and Social Affairs. 2018 Revision of World Urbanization Prospects. Recovered from https://www.un.org/development/desa/publications/2018revision-of-world-urbanization-prospects.html

Wentz, E., \& Gober, P. (2007). Determinants of small-area water consumption for the City of Phoenix, Arizona. Water Resources Management, 21, 1849-1863.

Worthington, A., \& Hoffman, M. (2008). An empirical survey of residential water demand modelling. Journal of Economic Surveys, 22(5), 842871. 